\title{
Bacteriophage-Mediated Control of Phytopathogenic Xanthomonads: A Promising Green Solution for the Future
}

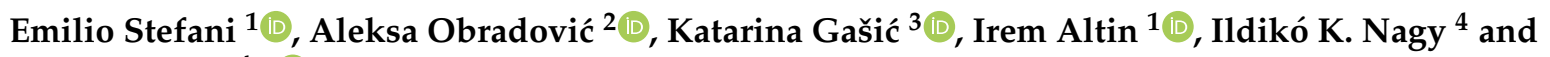 \\ Tamás Kovács $4, *$ (D) \\ 1 Départements of Life Sciences, University of Modena and Reggio Emilia, via Amendola 2, \\ 42122 Reggio Emilia, Italy; emilio.stefani@unimore.it (E.S.); irem.altin@unimore.it (I.A.) \\ 2 Plant Pathology Department, Faculty of Agriculture, University of Belgrade, Nemanjina 6, \\ 11080 Belgrade-Zemun, Serbia; aleksao@agrif.bg.ac.rs \\ 3 Institute for Plant Protection and Environment, Teodora Drajzera 9, 11040 Belgrade, Serbia; \\ gasickatarina@yahoo.com \\ 4 Nanophagetherapy Center, Enviroinvest Corp., Kertvaros u. 2, 7632 Pecs, Hungary; \\ nagy.ildi.kata@gmail.com \\ * Correspondence: microbiology@kovacstamas.com
}

check for

updates

Citation: Stefani, E.; Obradović, A.; Gašić, K.; Altin, I.; Nagy, I.K.; Kovács, T. Bacteriophage-Mediated Control of Phytopathogenic Xanthomonads: A Promising Green Solution for the Future. Microorganisms 2021, 9, 1056. https://doi.org/10.3390/ microorganisms 9051056

Academic Editor: Michael Hynes

Received: 31 March 2021

Accepted: 11 May 2021

Published: 13 May 2021

Publisher's Note: MDPI stays neutral with regard to jurisdictional claims in published maps and institutional affiliations.

Copyright: (C) 2021 by the authors. Licensee MDPI, Basel, Switzerland. This article is an open access article distributed under the terms and conditions of the Creative Commons Attribution (CC BY) license (https:// creativecommons.org/licenses/by/ $4.0 /)$.

\begin{abstract}
Xanthomonads, members of the family Xanthomonadaceae, are economically important plant pathogenic bacteria responsible for infections of over 400 plant species. Bacteriophage-based biopesticides can provide an environmentally friendly, effective solution to control these bacteria. Bacteriophage-based biocontrol has important advantages over chemical pesticides, and treatment with these biopesticides is a minor intervention into the microflora. However, bacteriophages' agricultural application has limitations rooted in these viruses' biological properties as active substances. These disadvantageous features, together with the complicated registration process of bacteriophage-based biopesticides, means that there are few products available on the market. This review summarizes our knowledge of the Xanthomonas-host plant and bacteriophage-host bacterium interaction's possible influence on bacteriophage-based biocontrol strategies and provides examples of greenhouse and field trials and products readily available in the EU and the USA. It also details the most important advantages and limitations of the agricultural application of bacteriophages. This paper also investigates the legal background and industrial property right issues of bacteriophage-based biopesticides. When appropriately applied, bacteriophages can provide a promising tool against xanthomonads, a possibility that is untapped. Information presented in this review aims to explore the potential of bacteriophage-based biopesticides in the control of xanthomonads in the future.
\end{abstract}

Keywords: bacteriophages; bacteriophage therapy; biological control; Xanthomonas spp.

\section{Introduction}

Plant diseases in pre- and post-harvest frequently account for $20 \%$ or more product losses, both in emerging countries as well as in developed areas [1]. Although less numerous than fungal diseases, bacterial diseases are often difficult to manage, due to their frequent polycyclic nature and the lack of systemic antibacterial substances [1]. Copper compounds and antibiotics are the only antibacterial choices to control phytopathogenic bacteria that are readily available in a large part of the world [2,3]. Copper presents several risks and unexpected consequences in agricultural systems and for the environment, e.g., phytotoxicity, negative effects on pollinating insects and other beneficial organisms, bioaccumulation in soil and surface water and reduction of microbial biodiversity [4-6]. Antibiotics, such as mainly streptomycin, kasugamycin and tetracyclines, as active substances in agriculture may also pose unacceptable risks when used as pesticides [3]. Indeed, although they do not accumulate or cause adverse effects on plants, they may incite the development of resistant traits in bacterial populations, including in the target pathogen(s), 
and transfer them to bacteria of clinical interest [7]. The urgent need to tackle pathogen control in agricultural systems using a more sustainable approach has directed research towards different strategies, among them the development and implementation of microbial biocontrol agents and bacteriophages [8,9]. In this review, we present the available knowledge on the use of bacteriophages in the management of xanthomonads, the largest group of phytopathogenic bacteria that are often the causal agents of devastating diseases in important crops. This review presents current knowledge on xanthomonads, bacteriophages, host-microbe interaction and ecology interactions. This information, -together with the description of results of relevant laboratory, greenhouse and field trials- supports the understanding of factors influencing the effectivity of bacteriophage-based biopesticides in the fields.

\subsection{Xanthomonads}

Xanthomonads are Gram negative bacteria belonging to the family of Xanthomonadaceae. Within this family Xanthomonas emerges as one of the most important genera in phytobacteriology, for it comprises around forty bacterial species pathogenic to over 400 plant species [10]. In turn, several Xanthomonas species are further taxonomically classified into different subspecies and pathovars, thus confirming a particular adaptation to plants. Such phytopathological adaptation is due to the expression of virulence factors [11,12]. Most Xanthomonas sp. strains are characterized by their production of xanthomonadin, a yellow pigment that represents the most useful diagnostic feature used for their identification [13], although a few pathovars are reported that do not produce such pigment, e.g.,: X. axonopodis pv. manihotis, X. campestris pv. mangiferaindicae and $X$. campestris pv. viticola $[14,15]$. Over the past 25 years, Xanthomonas species have undergone thorough changes in nomenclature based on phenotypic and conventional molecular techniques and, more recently, whole-genome sequencing (WGS) [16,17]. Indeed, evolutionary dynamics renders Xanthomonas species as rapidly evolving microbes and they are particularly successful as plant pathogens $[14,18]$.

Several devastating plant diseases are caused by xanthomonads, for example $X$. oryzae pv. oryzae is the causal agent of bacterial blight, the most serious disease of rice. Together with pv. oryzicola, the causal agent of bacterial leaf streak, both pathogens frequently represent a limiting factor constraining rice production in tropical and subtropical regions [19]. Both pathogens exhibit large genetic variation among isolates, thus accounting for a high genetic plasticity [12].

The bacterial canker of citrus, incited by X. citri subsp. citri affects all commercial varieties of citrus [20]. Two other major crops are affected by xanthomonads: bananas (all types), affected by bacterial wilt caused by $X$. vasicola pv. musacearum and cassava, affected by bacterial wilt caused by X. phaseoli pv. manihotis [21]. International trade and climate change appear fundamental to support dissemination of xanthomonads worldwide and their adaptation and establishment in new areas, as several recent findings confirm [22-24].

\subsection{Biological Control of Xanthomonads}

Biological control of plant pathogenic bacteria may be implemented in several ways, for example (1) using microbial antagonists producing specific substances, such as bacteriocins (antibiosis), (2) using beneficial bacteria to efficiently compete for nutritional resources in planta [25], or (3) applying microbes that produce anti-Quorum Sensing factors [26], or (4) act as hyperparasites [27]. Emerging biocontrol strategies for plant pathogens, and for xanthomonads in particular, increasingly rely on the use of selected microbial biocontrol agents, or microbiome engineering [28,29]. Several microorganisms can efficiently control xanthomonads, both in vitro and in vivo, with some also showing plant growth promoting traits [30]. Specifically, bacterial species belonging to the genera Pseudomonas and Bacillus are reported to be effective against several Xanthomonas spp. A large number of papers describe satisfactory results on the biocontrol of $X$. citri pv. citri, X. campestris pv. campestris and $X$. vesicatoria [28], but most described results were obtained in vitro or in a controlled 
environment. Conversely, reproducibility of such published results in agricultural systems is not as good as expected, possibly due to the differences in agricultural context and the cropping systems. Nonetheless, a few commercial products based on microbial biocontrol agents that have satisfactory antibacterial activity are readily available on the market. For instance, Serenade ${ }^{\circledR}$ and Serenade ${ }^{\circledR}$ Max (Bayer Crop Science, Leverkusen, Germany) based on a selected strain of Bacillus subtilis, are indicated for the biological control of X. arboricola pv. pruni. Similarly, Double Nickel ${ }^{\mathrm{TM}}$ LC (Certis, Columbia, MD, USA) based on a strain of Bacillus amyloliquefacies, is indicated for the biological control of the tomato spot disease (X. perforans).

\subsection{Bacteriophages}

Bacteriophages are viruses that specifically infect bacteria and have no direct negative effects on animals or plants. Bacteriophages are widely distributed on the Earth and are measurable components of the natural microflora [31]. In agricultural environments there are multiple sources of bacteriophages, such as healthy and diseased plant organs, soil, surface water, sewage and sludge, particularly from processing plants [32]. Bacteriophages may have different life cycles in natural environments. This includes a lytic life cycle, where a bacteriophage infects its bacterial host cell and rapidly induces its breakdown and a lysogenic cycle, where they are able to integrate their injected DNA into the bacterial genome [33].

Together with research on bacteriophages as prospective biocontrol agents (detailed in the Section 3), a number of studies were devoted to elucidating bacterial taxonomy. Bacteriophages have been used as tools to identify and characterize phytopathogenic bacteria [34]. Then, the use of specific bacteriophages appeared to be essential for population studies of phytopathogenic bacteria, in order to unravel key epidemiological factors. This supported the successful use of phages in controlling bacterial diseases [35].

Recent publications on isolation and characterization of bacteriophages against xanthomonads are summarized in Table 1.

Table 1. List of recent publications on bacteriophages against Xanthomonas spp.

\begin{tabular}{|c|c|c|}
\hline $\begin{array}{l}\text { Host Bacteria, Disease Name } \\
\text { and Host Plant }\end{array}$ & Description of Works Performed & Reference \\
\hline $\begin{array}{l}\text { Xanthomonas fragariae Angular } \\
\text { leaf spot in strawberry }\end{array}$ & $\begin{array}{l}\text { Isolation and whole genome sequence analysis of N4-like bacteriophage, named } \\
\text { RiverRider, including its host range. }\end{array}$ & {$[36]$} \\
\hline $\begin{array}{l}\text { Xanthomonas citri Asian citrus } \\
\text { canker }\end{array}$ & $\begin{array}{l}\text { Isolation and genome sequence analysis of Xanthomonas virus } \mathrm{XacN1} \text {, a novel jumbo } \\
\text { myovirus, showing a wider host range then other X. citri bacteriophages. }\end{array}$ & [37] \\
\hline \multirow{4}{*}{$\begin{array}{l}\text { Xanthomonas oryzae pv. oryzae } \\
\text { Bacterial leaf blight of rice }\end{array}$} & $\begin{array}{l}\text { Characterization of a novel phage Xoo-sp2, isolated from soil and its potential as a } \\
\text { prophylatic agent in biocontrol of the disease. }\end{array}$ & [38] \\
\hline & Isolation and complete genome sequence analysis of bacteriophage Xoo-sp13. & [39] \\
\hline & $\begin{array}{l}\text { Isolation and complete genome sequence analysis of a jumbo bacteriophage, } \\
\text { Xoo-sp14. }\end{array}$ & {$[40]$} \\
\hline & $\begin{array}{l}\text { Isolation and analysis of the complete genome sequences of } 10 \text { OP2-like X. oryzae pv. } \\
\text { oryzae bacteriophages }\end{array}$ & [41] \\
\hline \multirow{2}{*}{$\begin{array}{l}\text { Xanthomonas campestris pv. } \\
\text { campestrisBlack rot disease of } \\
\text { kohlrabi }\end{array}$} & $\begin{array}{l}\text { Evaluation of lytic activity of } \mathrm{Xcc} \varphi 1 \text { bacteriophage in combination with } \\
\text { 6-pentyl- } \alpha \text {-pyrone (a secondary metabolite produced by Trichoderma atroviride P1) } \\
\text { and the mineral hydroxyapatite for the prevention and eradication of bacterial } \\
\text { biofilms. }\end{array}$ & {$[42]$} \\
\hline & $\begin{array}{l}\text { Isolation and characterization of specific bacteriophage }(X \operatorname{cc} \varphi 1) \text { able to control } \\
\text { disease, and investigation of } X \text {. campestris pv. campestris and } X \operatorname{cc} \varphi 1 \text {, applied singly } \\
\text { or combined, on plant metabolome. }\end{array}$ & [43] \\
\hline $\begin{array}{l}\text { Xanthomonas campestris pv. } \\
\text { Campestris Black rot of } \\
\text { crucifers }\end{array}$ & $\begin{array}{c}\text { Isolation of phage infecting } X . \text { campestris pv. campestris and characterization of the } \\
\text { bacteriophage Xcc9SH3. }\end{array}$ & [44] \\
\hline
\end{tabular}


Table 1. Cont.

\begin{tabular}{|c|c|c|}
\hline $\begin{array}{c}\text { Host Bacteria, Disease Name } \\
\text { and Host Plant }\end{array}$ & Description of Works Performed & Reference \\
\hline $\begin{array}{l}\text { Xanthomonas campestris pv. } \\
\text { Campestris Black rot of } \\
\text { caulifower }\end{array}$ & $\begin{array}{l}\text { Isolation and morphological, molecular and phylogenetic characterization of X. } \\
\text { campestris pv. campestris specific bacteriophage named "Xanthomonas virus XC } 2 \text { " }\end{array}$ & [45] \\
\hline \multirow{2}{*}{$\begin{array}{l}\text { Xanthomonas arboricola pv. } \\
\text { Juglandis Walnut blight }\end{array}$} & $\begin{array}{l}\text { Isolation of } 24 \text { phages from soil and infected walnut aerial tissues. Two polyvalent } \\
\text { bacteriophages, were characterized by their morphological, physiological and } \\
\text { genomic analyses. }\end{array}$ & [46] \\
\hline & $\begin{array}{l}\text { Isolation and complete genome analysis of three bacteriophages, f20-Xaj, f29-Xaj and } \\
\text { f30-Xaj, specific to X. arboricola pv. juglandis }\end{array}$ & [47] \\
\hline \multirow{2}{*}{$\begin{array}{l}\text { Xanthomonas vesicatoria } \\
\text { Bacterial spot of pepper }\end{array}$} & $\begin{array}{l}\text { Isolation and complete genome sequence of a filamentous bacteriophage XaF13 } \\
\text { infecting X. vesicatoria }\end{array}$ & [48] \\
\hline & Isolation and complete genome sequence of $X$. vesicatoria bacteriophage $\Phi$ XaF18 & [49] \\
\hline
\end{tabular}

\section{Xanthomonas-Host Plant and Bacteriophage-Host Bacterium Interactions and Their Possible Influence on Bacteriophage-Based Biocontrol Strategies}

No species is an island, as each individual organism is constantly in contact with others [50]. Here we discuss bacteriophage-host bacterium interactions and the factors that influence the possible outcomes of bacterial infection of the host plant. The presented data is helpful when identifying the non-satisfactory efficacy of bacteriophage-based pesticides when applied on the field and maybe useful when designing integrated plant management (e.g., with the involvement of other biopesticides). We provide possible solutions and explain why bacteriophage products may have distinct efficacies when applied on different fields. We will also analyze the applicable Xanthomonas-plant interactions from the point of view of biocontrol and the relevant bacteriophage-bacterium interactions. Finally, we will investigate the mechanisms of bacteriophage resistance of bacteria.

\subsection{Xanthomonas-Host Plant Interactions}

Bacteriophage-based biocontrol treatments of xanthomonads intend to interfere with a plant-pathogenic Xanthomonas spp. system. This subsection contains essential information on this system.

Xanthomonads live part of their life cycle outside the host plant as epiphytes in the lesions of fallen leaves or associated to plant debris in the soil [51]. They are an essential component of the soil microbiome, with $2-7 \%$ relative abundance in the bacterial community [52].

The infection cycle of Xanthomonas spp. starts with an epiphytic phase followed by entering the host plant through natural openings (stomata, hydathodes) and wounds to start its internal colonization (endophytic phase) [53]. When introduced into the plant surface, xanthomonads use a variety of adhesion strategies to attach to the plant [54-59]. Plants have also evolved various defence mechanisms to protect themselves from pathogens [60]. They respond to pathogen associated molecular patterns (PAMPs) by activating PAMP-triggered immunity (PTI) or effector-triggered immunity (ETI) mediated by pathogen-specific receptors [61]. As a result, a systemic acquired resistance (SAR) status may be established, potentially increasing resistance to subsequent attacks in the entire plant [62-64].

A first key element of bacterial survival in the phyllosphere is the biofilm formation, creating a microenvironment that can protect bacteria against environmental stress conditions $[58,65]$. This is an important virulence factor of phytopathogenic Xanthomonas spp. [66,67]. A biofilm, in addition to the cells, is primarily made up of proteins, lipids and extracellular polysaccharides (EPS) [68,69]. The formation of a biofilm may provide resistance to host defence mechanisms and vascular bacteria attachment to xylem vessels, or contribute to bacterial epiphytic survival prior to colonisation of the plant intercellular space [70]. The gum operon, a massive transcriptional unit containing 12 enzyme coding genes (gumB- 
gum M), mediates xanthan gum biosynthesis [71]. A study revealed that biofilm production deficient mutants (particularly gumB and gumD) showed significantly lower leaf surface survival than wild type X. citri pv. citri and X. axonopodis pv. manihotis [72-74]. The study of many Xanthomonas spp. have shown that gum genes contribute to bacterial in planta growth, epiphytic survival and disease symptom formation [72,75-78].

The assembly and dispersal of biofilms are partly mediated by the Quorum-sensing (QS) signal molecule, or diffusible signal factor (DSF). DSF positively influences the disruption of biofilms [79].

One survival strategy of bacteria during unfavorable conditions is the formation of persister cells. Persisters are a small fraction $(0.001 \%-0.1 \%$, or up to $1 \%$ in biofilms) of cells in a metabolically inactive, dormant state that are resistant against a wide range of antibiotics [80]. X. campestris pv. campestris and X. citri subsp. citri can form persister cells under different stress conditions [81,82]. Importantly, bacteriophages can also infect persisters [83].

LPS, as major components of the bacterial outer membrane, protect the cell from harmful environments and are another surface-associated virulence factor in Xanthomonas spp. Importantly, LPS not only function as virulence factors but also induce plant defense responses, such as pathogenesis-related gene expression, cell wall thickening and oxidative burst $[84,85]$. Mutations in LPS gene clusters make bacteria more susceptible to adverse environmental conditions, which may result in a reduction in bacterial virulence, as shown for X. campestris pv. campestris [86-88].

Xanthomonas species have a plethora of potential mechanisms that aid bacterial fitness in diverse environments, including the six different extracellular protein secretion systems (referred to as type I-VI, or T1SS-T6SS) that export proteins via the bacterial multilayer cell envelope and, in some cases, into host target cells. The conserved structural components that characterize these secretion systems, as well as the characteristics of their substrates and the pathway that these substrates take during the export process, distinguish them. T6SS was recently discovered and is involved in at least $25 \%$ of all sequenced gramnegative bacterial genomes [89]. The $H c p$ and $V g r G$ proteins are essential components of T6SS that mimic the bacteriophage tail and needle complex, respectively [90]. Yang et al. [90] investigated the evolution of the T6SS in the Xanthomonas genus and assessed the relevance of the T6SS for virulence and in vitro motility in X. phaseoli pv. manihotis (Xpm), the causal agent of cassava bacterial blight. According to their phylogenetic analyses, the T6SS may have been obtained through a very ancient event of horizontal gene transfer (HGT) and preserved through evolution, implying their significance for host adaptation. They also showed that the T6SS of Xpm is functional and immensely contributes to motility and virulence.

Transcription activation-like effectors (TALEs) ensure plasticity in host adaptation for xanthomonads. TALEs have a repetitive domain governing the binding to promoters of host genes [91]. Novel TALEs could be created because this repetitive region is shared among TALEs, and recombination frequently occurs, as it was recently demonstrated in $X$. oryzae pv. oryzae [92]. These novel TALE encoding genes could be changed by HGT between bacteria, strengthening their host adaptation abilities [93].

\subsection{Bacteriophage-Host Bacterium Interactions}

When investigating ecological roles of bacteriophages in a Xanthomonas spp. population, it should be highlighted that the relationship between bacteriophages and their hosts could be both antagonistic and mutualistic, and the long-term survival of a bacteriophage population does not always require the lysis of its host. Therefore, bacteriophages are not predators, but either parasites or parasitoids of the host [94].

Bacteriophages can infect bacteria located in biofilms, albeit biofilms can provide a barrier for bacteriophage attacks compared to planktonic bacteria. This barrier is due to the physiological heterogeneity of the bacteria composing the biofilms, the secreted EPS, and the differential display of receptors on the host cell' surface [94]. Bacteriophages can inter- 
act with biofilms of xanthomonads at several points. In a recent study Yoshikawa et al. [37] isolated the X. citri jumbo bacteriophage XacN1. They showed that the XacN1 genome encodes potential lytic enzymes such as cell wall hydrolases, C1 family peptidase, M23 family peptidases, lipase and chitinase. According to proteomic analysis, lipase, chitinase, and M23 family peptidases were discovered in the bacteriophage XacN1. They concluded that these enzymes may be necessary to disrupting the biofilm and initiating bacteriophage infection. Bacteriophages have evolved to counteract the biofilm barrier by using depolymerase enzymes on their capsids, and can also induce host lysis, allowing bacteriophages to degrade biofilm [95]. Furthermore, bacteriophage genomes carrying QS genes were detected in Clostridium difficile bacteriophage phiCDHM1 and three Paenibacillus bacteriophage genomes [96-98]. These genes can modify the biofilm disruption and other QS-mediated responses, including the decision on the lysogenic or lytic lifecycle of bacteriophages [97] or even the synthesis of virulence genes, as demonstrated in X. campestris [98].

Generally, the diversity of bacterial communities can support their adaptation to environmental circumstances [99]. If a community is more diverse, it is more stable as it can better adapt to the changing environment [100]. Prokaryotic viruses are essential in driving processes in microbial ecosystems [101,102]. In the absence of bacteriophages, one or several strains could become dominant in the niche, and other strains could be extinct, as was demonstrated in in vitro experiments [101,103]. Bacteriophages most likely infect the most abundant host strain, causing a decrease in its abundance ("kill the winner" principle). A consequence of this action will be a fluctuating selection, that increases diversity [103] and strengthens the community's stability or adaptation ability. This may cause that bacteriophage-based pesticides can support the presence of xanthomonads on the fields when not applied carefully. Integrated disease management together with the application of carefully selected bacteriophages timed appropriately could be one solution.

The genome of lysed cells will be available for surrounding bacteria, providing them novel genetic information, which may also include pathogenicity-related genes, as recently shown in the case of the cherry pathogen Pseudomonas syringae pv. morsprunorum or in $X$. albilineans $[104,105]$. Lytic bacteriophages increase the mutation rate in their host's genome, even in genes not related to bacteriophage resistance/immunity [101]. This effect can drive both adaptation (short term) or evolution (long term) processes. These from point of biocontrol disadvantageous features of lytic bacteriophages (i.e., providing novel genetic material for surrounding bacteria, increasing the mutation rate in the host's genome) could be managed by an integrated disease management. However, the mentioned drawbacks are less serious, for example, when lysogenic bacteriophages are applied in the fields. Lysogenic bacteriophages can protect bacteria carrying their genomes from superinfection (Superinfection: A second (delayed) bacteriophage infection of an already bacteriophageinfected bacterium) [106]. Horizontal gene transfer is one of the major factors (together with the mutations in avirulence genes) to evade host resistance [107-109]. The fact that $5-25 \%$ of the genome of Xanthomonas spp. originates from recombination events [110] highlights its importance in xanthomonads evolution and adaptation processes. Exchange of virulence factors between Xanthomonas spp. via HGT was observed in several cases [12].

The complexity of these HGT actions is demonstrated in the genome of a X. anoxopodis strain that contains a truncated bacteriophage genome carrying a gene resembling a plant protein that is induced during citrus blight disease [111].

As bacteriophages are often strain-specific, they can also act on the population level, influencing the population's intraspecific composition. Consequently, lysogens can contribute to the colonization of new niches. When lysis is induced in a small portion of the lysogenic cells, from superinfection-protected bacterial populations, and the bacteria originally located in the niche to be colonized are not protected from the infection, the new population can use their lysogenic bacteriophages as a weapon against the indigenous cells ("kill the relatives" principle) [101]. On the contrary, native bacteria can protect themselves against colonization by sacrificing a part of the population and inducing their prophages' 
lytic cycle [101]. Lysogenic bacteria can use their prophage weapon effectively, as observed in an in vitro experiment recently, where a lysogenic-lytic switch of bacteriophages to QS autoinducers strongly influenced the viral and bacterial abundance and diversity in soil communities [112].

There are examples of how lytic induction is carried out to optimize the multiplicity of infection (MOI). QS, encoded by either bacteria or bacteriophages, can influence this process $[113,114]$. Moreover, some bacteriophage genomes contain their own density monitoring equipment (the arbitrium system) and encode for small oligopeptides with which the bacteriophage density can be measured, as described in Bacillus bacteriophages [114,115]. Lysogeny is preferred when bacteriophages are abundant. Based on the described features of lysogenic and transducing bacteriophages, their field application may contribute to the adaptation and pathogenicity of xanthomonads, i.e., it may lead to unwanted effects. Therefore, the application of well-characterized, strictly lytic bacteriophages is advisable for bacteriophage-based biocontrol.

As bacteriophages and their hosts are not alone in the microflora, bacteriophages will meet their hosts with rare frequency when the living cell number of the host is low. Thus, one important consequence of the "kill the winner" principle is that bacteriophages cannot reduce the living cell number of their hosts to zero in a community [116], a property which differs from most chemical antibacterial compounds.

We mentioned examples in this subsection, how bacteriophages (both lytic and lysogenic ones) can alter the strain and/or species abundancies in communities. The composition of Xanthomonas spp. population and/or the microbial community may be distinct in different fields which may be differentially influenced by the described effects of bacteriophages. In addition to the environmental factors, a result of this divergent influence may lead to a distinct outcome of bacteriophage-based biocontrol in fields, at least in several cases [117].

\subsection{Bacteriophage Resistance in Bacteria}

Bacteriophage-resistance mutations in bacteria usually come with a fitness cost, such as a decrease in virulence, which results in less disease severity. This is because many of the molecules taking part in bacteriophage attachment are also engaged in the virulence mechanism. As a result, mutations that lead to resistance commonly compromise virulence. There are a few examples of how mutations in bacteria surface structures lead to decreased virulence, such as mutation in the X. campestris xanA gene needed for xanthan and lipopolysaccharide synthesis, which significantly decreases the effectiveness of bacteriophage L7 adsorption [118].

Bacteriophage resistance in bacteria is one of the main concerns regarding the bacteriophagebased biocontrol strategies. A detailed understanding of bacterial resistance to bacteriophages and their interaction with plants play an important role in the design of bacteriophagebased biocontrol strategies of xanthomonads. To survive bacteriophage infections, bacteria have developed a wide range of protection strategies, including spontaneous mutations, restriction modification systems ( $\mathrm{R}-\mathrm{M}$ systems), and adaptive immunity through the CRISPR-Cas system [106]. The key mechanisms driving bacteriophage resistance are spontaneous mutations, which can grant bacteriophage resistance by altering the structure of bacterial surface components that function as bacteriophage receptors [119]. Furthermore, bacteria can acquire resistance through lysogenic bacteriophages that carry sequences in their genetic material which encode bacterial resistance or toxins and incorporated into the bacterial genome [120]. The mechanisms by which bacteriophages counteract the antibacteriophage systems of bacteria are poorly understood. Bacteriophages with the ability to acquire new receptor tropism can modify their receptor-binding protein, which means that when a host receptor changes to a mutated form, bacteriophages can recognize the altered receptor structure and thus overcome disturbance in receptors for bacteriophage adsorption [121]. Bacteriophages use various anti-restriction strategies to avoid the wide range of $\mathrm{R}-\mathrm{M}$ systems. These modification genes encode a small protein that is transmitted 
to the cell with the viral genome, or it may instantly neutralize the host immune system by intervening with the formation or function of the CRISPR-Cas ribonucleoprotein [122]. Bacteriophages may use bacterial CRISPR-Cas systems to promote their own replication, allowing the phage to complete its lytic cycle [123]. When a bacterium develops resistance to a specific bacteriophage, it retains sensitivity to bacteriophages with various cell surface receptors. Bacteriophage-mediated selection can be used in disease management, for example, by combining various bacteriophages to broaden the host range and suppress resistance evolution [124] and/or reasonably combining bacteriophages and chemical control to establish synergies and decrease the likelihood of resistance evolution [125]. This implies that the application of a bacteriophage cocktail may be beneficial, even if bacteria quickly develop resistance, since resistant strains may be less fit, thus more treatable using another combined method.

\section{Bacteriophage-Based Biocontrol of Xanthomonas spp.}

\subsection{Examples for Greenhouse and Field Trials}

Shortly after their discovery, bacteriophages were evaluated for control of plant diseases, including those caused by Xanthomonas spp. Some of the first studies were conducted by Mallman and Hemstreet (1924) who isolated the "cabbage-rot organism" $X$. campestris pv. campestris from rotting cabbage and showed that the filtrate from the decomposed tissue could inhibit pathogen growth in vitro [126].

From the 1960s, a considerable number of studies explored the efficacy of phages for the control of bacterial spot of peach, caused by X. arboricola pv. pruni [127-130]. Civerolo and Keil [127] applied bacteriophages $1 \mathrm{~h}$ prior to inoculation by the pathogen and reduced bacterial spot severity on peach leaves to $22 \%$ compared to $58 \%$ for control plants under greenhouse conditions. Civerolo [128] found that preinoculation of peach seedling foliage with crude lysates of the bacteriophage mixtures resulted in 6-8\% fewer infected leaves and a $17-31 \%$ reduction of disease compared to control plants. Application of premixed bacteriophage-pathogen suspension immediately before inoculation resulted in a 51-54\% decrease of bacterial spot symptoms in peach seedlings. Zaccardelli et al., isolated eight bacteriophages active against $X$. arboricola pv. pruni, examined their host range and lytic ability, and selected a lytic bacteriophage strain with the broadest host range for disease control $[129,130]$. By weekly bacteriophage treatment they significantly reduced fruit spot incidence on peaches [130].

Significant achievements have been made in bacteriophage application for control of bacterial spot of tomato caused by X. campestris pv. vesicatoria in greenhouse and field conditions [131-138]. Flaherty et al. [131] used a mixture of host range mutant bacteriophages and effectively controlled tomato bacterial spot in greenhouse and field conditions. Moreover, bacteriophage application increased total weight of extra-large fruit comparing to nontreated control or plants treated with chemical bactericides. Balogh et al. [133] improved the efficacy of bacteriophage treatments in field and greenhouse experiments by using protective formulations that significantly increased bacteriophage longevity on the plant surface. Bacteriophage mixture formulated either with $0.5 \%$ pregelatinized corn flour, Casecrete NH-400 with $0.25 \%$ pregelatinized corn flour, or $0.75 \%$ powdered skim milk with $0.5 \%$ sucrose, provided significant disease control compared to untreated control. However, in greenhouse experiments skim milk gave the best results, while Casecrete performed best in the field [133].

In order to improve bacteriophage efficacy and provide consistent disease control, bacteriophages of $X$. campestris pv. vesicatoria have been studied as a part of integrated disease management practices [138]. Obradovic et al., tested various combinations of plant inducers and biological agents for control of tomato bacterial spot [139]. AcibenzolarS-methyl applied in combination with bacteriophages formulated with skim milk and sucrose, reduced bacterial spot of tomato in a greenhouse [136] as well as in the field [135]. Recently, Abrahamian et al. [140] evaluated 19 different chemical agents, biological control agents, plant defense activators, and novel products for their ability to manage bacterial 
spot on tomato caused by X. perforans. They reported that combination of bacteriophages, cymoxanil, famoxadone and phosphoric acid, significantly improved the disease management compared to the copper-based standard treatment. All these studies led to bacteriophage treatment, integrated with other disease management practices (e.g., late blight), becoming a part of a standard integrated management program for tomato bacterial spot in Florida $[138,139]$.

Gašić et al. [141] studied the efficacy of bacteriophage $\mathrm{K} \phi 1$ in the control of pepper bacterial spot caused by X. euvesicatoria. They found that double bacteriophage application, before and after challenge inoculation, significantly reduced disease incidence when compared to untreated control. However, integrated application of bacteriophages $2 \mathrm{~h}$ before and copper hydroxide $24 \mathrm{~h}$ before inoculation was the most efficient treatment. The same bacteriophage strain was used as a part of integrated disease management and combined with other biocontrol agents, copper compounds, antibiotics and plant inducers to control pepper bacterial spot [142]. Bacteriophage combination with copper-hydroxide and acibenzolar-S-methyl was the most effective treatment reducing the disease severity by $96-98 \%$ compared to control [142].

Similar studies were performed to develop management strategies for efficient and sustainable control of leaf blight of onion, caused by X. axonopodis pv. allii. Lang et al. [143] reported that biweekly or weekly applications of bacteriophages reduced disease severity in the field by 26 to $50 \%$ : similar to results achieved by weekly applications of coppermancozeb. Therefore, integrated application of bacteriophage mixtures with acibenzolar-Smethyl could be a promising strategy for managing Xanthomonas leaf blight of onion and contribute to reduced use of chemical bactericides [143].

Comprehensive research was done on bacteriophage-mediated control of Asiatic citrus canker caused by $X$. axonopodis $\mathrm{pv}$. citri, and citrus bacterial spot $X$. axonopodis $\mathrm{pv}$. citrumelo [144-146]. Bacteriophage treatment, without skim milk formulation, provided an average $59 \%$ reduction in citrus canker severity in greenhouse experiments. In nursery, bacteriophage treatment reduced disease, but was less effective than copper-mancozeb, while bacteriophage integration with copper-mancozeb resulted in equal or less control than copper-mancozeb application alone [145]. Similar results were obtained in the management of citrus bacterial spot, where bacteriophage treatment provided significant disease reduction on moderately sensitive Valencia oranges while it was ineffective on the highly susceptible grapefruit [145]. Ibrahim et al. [146] reported that successful control of Asiatic citrus canker in greenhouse and field can be obtained by combination of bacteriophage mixture formulated with skim milk-sucrose and acibenzolar-S-methyl.

Initial research of bacteriophage infecting X. oryzae pv. oryzae, the causal agent of bacterial blight of rice, was conducted by Kuo et al., who applied purified bacteriophages 1, 3, and 7 days before inoculation, and obtained $100 \%, 96 \%$ and $86 \%$ reductions of bacterial leaf blight, respectively [147]. Recently, Chae et al. [148] significantly reduced the occurrence of bacterial leaf blight to $18.1 \%$ compared to $87 \%$ in untreated control by treatment with skim milk formulated bacteriophages. Ogunyemi et al. [149] reported the bacteriophage X3 was more effective in disease severity reduction $(83.1 \%)$ if sprayed before inoculation rather than after (28.9-73.9\%) it. However, seed treatment with bacteriophages reduced disease by $95.4 \%$.

Other results on using bacteriophages specific to Xanthomonadaceae in plant disease control includes reduction of incidence of bacterial blight of geraniums caused by $X$. campestris pv. pelargonii with foliar application of h-mutant bacteriophages [150]. Nagai et al. [151] found that a non-pathogenic Xanthomonas sp. strain mixed with bacteriophages effectively controlled black rot of broccoli caused by X. campestris pv. campestris in field trials. Orynbayev et al. (2020) studied effects of bacteriophage suspensions mixed with different UV-protectants in control of black rot caused by X. campestris pv. campestris on cabbage seedlings. In two-year greenhouse experiments, bacteriophage DB1 mixed with $0.75 \%$ skimmed milk showed an average efficacy of $71.1 \%$ in control of the disease, compared to $59.1 \%$ efficacy of Kocide 2000 treatment [152]. 
A list of recent studies regarding bacteriophage-based biocontrol of diseases caused by Xanthomonas spp. is presented in Table 2.

Table 2. List of recent studies of bacteriophage-based biocontrol for diseases caused by Xanthomonas spp.

\begin{tabular}{|c|c|c|c|}
\hline Level & $\begin{array}{l}\text { Host Bacteria, Disease } \\
\text { Name and Host Plant }\end{array}$ & Description of Works Performed & Reference \\
\hline \multirow{6}{*}{$\begin{array}{l}\text { Greenhouse and } \\
\text { field trials against } \\
\text { xanthomonads }\end{array}$} & & $\begin{array}{l}\text { Characterization and whole genome analysis of } K \Phi 1 \text { phage } \\
\text { infecting } X . \text { euvrsocatoria. Single bacteriophage treatment as } \\
\text { well its integarion with copper-hydrovide was evaluated in } \\
\text { greenhouse conditions. }\end{array}$ & {$[141]$} \\
\hline & $\begin{array}{l}\text { Xanthomonas euvesicatoria } \\
\text { Bacterial spot of pepper }\end{array}$ & $\begin{array}{l}\text { Study of efficacy of biocontrol agents (bacteriophage K } \Phi 1 \text { and } \\
\text { two strains of Bacillus subtilis AAac and QST 713), systemic } \\
\text { acquired resistance inducer (acibenzolar-S-methyl), a } \\
\text { commercial microbial fertilizer (Slavol), copper-based } \\
\text { compounds (copper hydroxide and copper oxychloride) in } \\
\text { combination with or without mancozeb, and antibiotics } \\
\text { (streptomycin sulphate and kasugamycin), in control of the } \\
\text { disease. }\end{array}$ & {$[142]$} \\
\hline & $\begin{array}{l}\text { Xanthomonas citri subsp. } \\
\text { Citri Asiatic citrus } \\
\text { canker }\end{array}$ & $\begin{array}{l}\text { Efficacy of applications of formulated bacteriophages with skim } \\
\text { milk and sucrose or nonformulated bacteriophages combined } \\
\text { with acibenzolar-S-methyl compared to copper bactericides } \\
\text { applications in control of the disease on leaves under } \\
\text { greenhouse and field conditions. }\end{array}$ & {$[146]$} \\
\hline & $\begin{array}{l}\text { Xanthomonas perforans } \\
\text { Bacterial spot of } \\
\text { tomatoes }\end{array}$ & $\begin{array}{l}\text { Evaluation of } 19 \text { different chemical agents, biological control } \\
\text { agents, plant defense activators, and novel products in control } \\
\text { of the disease on tomato seedlings and in the field. }\end{array}$ & {$[140]$} \\
\hline & $\begin{array}{l}\text { Xanthomonas campestris } \\
\text { pv. Campestris Black rot } \\
\text { of broccoli }\end{array}$ & $\begin{array}{l}\text { Study of the potential of nonpathogenic Xanthomonas sp. strain } \\
11-100-01(\mathrm{npX}) \text { mixed with bacteriophage XcpSFC211 (pXS) in } \\
\text { control of disease in greenhouse and field conditions. }\end{array}$ & {$[151]$} \\
\hline & $\begin{array}{l}\text { Xanthomonas campestris } \\
\text { pv. Campestris Black rot } \\
\text { of cabbage }\end{array}$ & $\begin{array}{l}\text { Evaluation of the effect of UV light factor on persistence of the } \\
\text { phage mixed with different UV-protectors in vitro and in planta } \\
\text { on young cabbage plants in greenhouse conditions, and its } \\
\text { efficacy in control of the disease. }\end{array}$ & {$[152]$} \\
\hline $\begin{array}{l}\text { Commercialized } \\
\text { products against } \\
\text { xanthomonads }\end{array}$ & $\begin{array}{l}\text { Xanthomonas campestris } \\
\text { pv. Vesicatoria bacterial } \\
\text { spot of tomato and } \\
\text { pepper }\end{array}$ & $\begin{array}{l}\text { AgriPhage, contains bacteriophages specific to } X \text {. campestris pv. } \\
\text { vesicatoria and Pseudomonas syringae pv. tomato for control of } \\
\text { bacterial spot or speck of tomato and pepper. }\end{array}$ & $\begin{array}{l}\text { Omnilytics, } \\
\text { nd. }\end{array}$ \\
\hline
\end{tabular}

\subsection{Advantages}

Low efficacy of available control strategies against xanthomonads is a consequence of the high multiplication rate of pathogens, high rate of pathogen mutation or gene transfer and thus increased population variability, as well as lack of efficient chemical treatments. Due to the difficulties in controlling Xanthomonas spp. incited diseases using conventional methods, considerable efforts were made to develop biologically based strategies.

Unlike chemical products for the treatment of bacterial diseases, application of bacteriophages has several advantages [138]. They have no toxic effects on the environment, and do not target eukaryotic cells [153]. Bacteriophages are self-replicating, and multiply exponentially upon infecting host bacteria. They are highly host specific, without affecting non-target organisms. Although they may vary in the host preferences, there are bacteriophage strains with a very narrow host range, infecting only a particular bacterial species or strain. Consequently, bacteriophages can be used against specific bacterial species without affecting beneficial microbial communities in the environment [154]. Thus, application of bacteriophages could contribute to maintaining beneficial or desired bacterial populations by suppressing the targeted ones. Additionally, bacteriophages can be used to target copper- and antibiotic-resistant bacteria, thus eliminating resistant strains $[140,155]$. 
They are suitable for mixing with the majority of chemical or biological crop protection products without significant effects on their efficacy [141-143]. They can be used to protect fresh-cut vegetables and fruits from post-harvest bacterial diseases [129] as well as human pathogens [156]. Additional advantages of using bacteriophages in plant protection come from their natural abundance and that their population dynamics is exclusively connected to the host bacterium's population changes. Thus, they fit well as biopesticides that can be used in organic production for eliminating bacterial pathogens.

\subsection{Limitations}

In the past, despite the promising early work, application of bacteriophages did not provide reliable and effective disease control [138]. Lack of knowledge about bacteriophage biology and epidemiology, complexity of different bacteria-bacteriophage systems and plant environment resulted in reduced interest in developing and implementing bacteriophage-based control strategies. As biological entities, bacteriophages are exposed to environmental factors (for example UV light and drought) that can limit their efficacy compared to synthetic bactericides' performance. Therefore, in-depth understanding of the optimal conditions for bacteriophage replication ability in the target environment is required [138,157]. Although bacteriophages may be effective in one crop, they may not be as effective in other pathosystems [158]. Optimization of their biocontrol activity requires a series of field experiments, since in vitro and greenhouse trials may not fully reflect the harsh conditions of the real environment and different crops. To improve survival of bacteriophages on plant phyllo- and rhizosphere, under ambient conditions, many adjustments are needed.

Major concern comes from the detrimental effect of the sunlight UV spectrum. Direct sunlight significantly reduces bacteriophage survival in the plant phyllosphere. Although available research results demonstrate that various substances can be used to protect bacteriophages from UV-induced decay, better formulations are still needed. Additionally, formulations are required to address the negative effect of desiccation as well as limited bacteriophage persistance on the plant surface. Timing of bacteriophage applications is essential for facilitating a high bacteriophage population reaching the target bacterium successfully, and for maximizing bacteriophages' efficacy in extremely harsh environments that affect their survival $[159,160]$. At least in the case of several commercial products (i.e., Erwiphage $^{\circledR}$ Plus, [161]) the producer suggest spraying the biopesticide after sunset.

Gill and Abedon [159] indicated that in the rhizosphere, the soil water content determines diffusion rate of bacteriophages through heterogeneous soil matrices. Due to low rates of bacteriophage diffusion and high rates of bacteriophage inactivation, low numbers of viable bacteriophages are available to lyse target bacteria. Biofilms can trap bacteriophages [162], soil clay particles can reversibly adsorb bacteriophages [163], and low soil $\mathrm{pH}$ can inactivate bacteriophages [164,165].

There is also a high probability of developing resistant bacterial strains to bacteriophages [166]. This may compromise the bacteriophage treatment efficiency, especially in case of using single strain or narrow host range bacteriophage strains. Application of bacteriophages in a cocktail could minimize this risk and offer a potential solution $[167,168]$. Using the strategy of bacteriophage application proposed by Jackson could also prevent occurrence of phage-resistant bacterial mutants [169]. In order to prevent emergence of resistant bacteria and maximize bacteriophage application effectiveness, the method of application, timing, mixture of several bacteriophage strains, association with protective compounds and/or amendment with non-host avirulent bacteria as a carrier should all be optimized. Eventually, the production process of a bacteriophage-based treatment needs to be optimized for stability, purity and quality of bacteriophage.

\subsection{Commercial Products}

In the last two decades, several bacteriophage-based products have been registered for control of bacterial plant diseases. OmniLytics, Inc., Sant Lake City, UT, USA, was the 
first company to receive EPA registration to use bacteriophages in agriculture. Their first bacteriophage-based bactericide, AgriPhage, contains bacteriophages specific to $X$. campestris pv. vesicatoria and Pseudomonas syringae pv. tomato for control of bacterial spot and speck of tomato and pepper. In addition, this company recently developed new bacteriophage-based biopesticides for control of tomato bacterial canker, fire blight of apple and pear, and citrus canker. Another company, Otsuka Pharmaceutical, developed XylPhi-PD, which contains bacteriophages infecting Xylella fastidiosa, the causal agent of Pierce disease of grape. This product was approved for use in the USA. In Europe, there are two companies with registered bacteriophage-based biopesticides: a Hungarian company Enviroinvest, developed Erwiphage ${ }^{\circledR}$ Plus for the control of fire blight of apple, and the Scottish company APS Biocontrol Ltd., designed Biolyse ${ }^{\circledR}$ PB, containing bacteriophages for the control of potato soft rots.

\section{Legal Basis for the Registration of Bacteriophage-Based Pesticides}

It is well known that microbial biocontrol agents (MBAs) are very promising biopesticides composed of living microorganisms. Although viruses should not be considered as such, the international regulatory framework groups viruses together with other true microorganisms, such as bacteria and fungi [170]. As for other pesticides, before registration and marketing, MBAs must undergo a thorough risk assessment to food safety and environmental fate [171]. The EU assessment procedure was first laid down in Directive 91/414/EEC, followed by regulation number 1107/2009 that repealed and succeeded the Directive. With its implementation, only $26 \%$ of registered active substances and Plant Protection Products (PPP) passed the review, compared with those under Directive 91/414/EEC [172]. Therefore, only one fourth of the active substances allowed in agriculture were not revoked, as a sign of increased attention to consumers' and environmental safety. In the USA, the regulatory framework appears less complex, since only two authorities are involved, namely the Environmental Protection Agency (EPA) and the Food and Drug Administration (FDA). Conversely, in the EU at least four major authorities are involved: The Rapporteur Member State, where the applicant submits a dossier containing all relevant information on the MBA, the European Food Safety Agency (EFSA), providing a risk assessment and risk communication, the Directorate General for Health and Food Safety (DG SANTE) and the Standing Committee on Plants, Animals, Food and Feed (PAFF Committee). The member states are divided into three evaluation zones. At the end of the process, requiring 26-36 months, the MBA can be included in the list of approved active substances.

A global overview on patenting bacteriophages is given by Holtappels et al. [173], where they found a good correlation between published papers and patent documents. Granted patent claims are rather broad and cover application methodology. The growing publishing and patenting activity indicates that there is a thorough interest in bacteriophages [173]. Conversely, very few authorized biopesticides based on bacteriophages are available on the market. EFSA, in a published opinion, excluded bacteriophages from the Qualified Presumption of Safety (QPS) $\left({ }^{*}\right)$ The Qualified Presumption of Safety (QPS) list is a list of microorganisms intentionally introduced into the food and feed production chain. It was first established in 2007 and it is revised and updated annually by EFSA in the framework of market authorization.) list as: (1) the lowest level of taxonomic unit (order of Caudovirales) is considered too broad; (2) lack of thorough analysis at the genome level to distinguish transducing and non-transducing bacteriophages or whether they carry virulence determinants [174]. Then, safety issues raised in the EU are leading to relatively strict regulations and registration protocols before the products can be placed on the market. Finally, Svircev et al. [9], framing the future of bacteriophages in agriculture, correctly identified potential problems with bacteriophages as biocontrol agents. Apart from the possible development of phage resistance in the bacterial host, true obstacles for the possible registration of bacteriophages as MBAs are represented by the production of lysogens or pseudolysogens and, additionally, that bacteriophages could serve as 
vectors for mobile genetic elements, including antibiotic resistance genes, as reported by other authors [175].

\section{Conclusions and Future Perspectives}

Bacteriophages have been studied as potential biocontrol agents to manage plant diseases caused by bacteria. In this review we have focused of bacteriophages of xanthomonads. To date, most studies have been conducted in the laboratory or under controlled conditions, most commonly in greenhouses and laboratories (discussed in Section 3), indicating the need for more field trials to ensure true applicability in open conditions.

There are multiple technological and biological opportunities to apply bacteriophages as biological pesticides in agriculture (as described in the subsequent paragraphs). For example, the use of endolysin increases the efficacy of bacteriophage biocontrol. Endolysins are enzymes used by bacteriophages at the end of their replication cycle to degrade the peptidoglycan membrane of the bacterial host from within, thereby lysing the cell and releasing progeny virions. The use of endolysin alone is effective only against Gram-positive bacteria, but a solution should necessarily be found for its use against Gram-negative bacteria. Artilysin, the outer membrane-penetrating endolysin, may offer this solution [176]. There are some newly discovered Gram-negative lysins that have roles principally against the major antibiotic resistant organisms causing nosocomial infections [177].

In order to enhance the efficacy of a bacteriophage-based biopesticide, it is highly desirable to apply it in the frame of an integrated plant protection (IPP) strategy (results and examples are detailed in Section 3). IPP strategies involve avoiding the disease outbreak, forecasting, detecting, and monitoring infections, designing biological interventions based on standardized principles, and measuring the effects of such interventions [178]. When designing a successful bacteriophage-based biocontrol strategy, the plant-pathogenbacteriophage interaction triangle should be considered [179]. For example, the titer and composition of the bacteriophage cocktail and the timing of treatment may require alterations based on targeting of an epiphytic pathogen compared to an endophytic pathogen. Additionally, the influence on bacteriophage cocktails of other chemical treatments on the same crop should be evaluated.

Another promising development is the absorption of bacteriophages into plants. Bacteriophage penetration into plants has been previously detected [180]. However, nowadays, bacteriophage-products exert their antimicrobial effects on the surface of the plants, therefore on bacteria during their epiphytic phase, and the proportion of incorporated bacteriophages is minimal [180].

Despite its promise, bacteriophage-mediated control of phytopathogenic bacteria has some limitations (detailed in Section 3.3).

One of the most significant limiting environmental factors with the use of bacteriophages in agriculture is the destructive effect of UV light. However, bacteriophages have been isolated against Pseudomonas syringae pv. actinidiae which can tolerate extended high UV-B doses [181]. In addition, a straightforward method for supporting the phages' survival in the environment is the utilization of bacterial bacteriophage carrier systems, as published recently [182]. In these systems, a non-pathogenic epiphytic bacterium strain is applied that can serve as biological control agent, bacteriophage delivery system and enables bacteriophage multiplication increasing its population on the plant surface [182].

However, besides the opportunities, the use of bacteriophages as a biopesticide may encounter some legal obstacles in the EU (detailed in Section 4). The use of viruses in therapy, even those that are beneficial and useful, is extremely provocative and controversial. Considering consumers perception, which is very sensitive to any microbe-based product when applied to food: this appears the most critical hurdle to be overcome in order for bacteriophages to be widely used in agriculture and elsewhere [183]. Researchers, therefore, have an extremely important and urgent task to tackle, collaborating with national leaders and decision-makers on bacteriophages and their potential use as sustainable plant protection products. Moving forward, it is essential for researchers to use previous 
data $[9,175,184]$ to expand this field of research, thereby strengthening support for the useful and safe applications of bacteriophages in plant protection among stakeholders and the public.

Bacteriophage-based pesticides could be positioned as premium products suitable for application when the use of chemical-based pesticides is not possible, for example the Erwiphage ${ }^{\circledR}$ Plus in Hungary [161]. To fulfil this role, end-users (farmers) should be informed of the biological features of these active compounds, and features of storage and application of these products should be optimized to be more user-friendly. One important area that requires optimization is the prolongation of the presence of infective bacteriophages in the orchard.

In conclusion, there is great, but currently yet unexploited, potential for bacteriophage use to replace or reduce the number of agrochemicals, such as copper and antibiotics, used for the control of bacterial plant pathogens, and xanthomonads in particular. To achieve this, the properties of bacteriophage-based products should be improved, pipelines of necessary characterization of the composed bacteriophages should be standardized, clear guidelines of application of bacteriophage-based biopesticides needed to be provided, and the registration process should be simplified, especially in the EU.

Author Contributions: Conceptualization, T.K.; Section 1, E.S.; Section 2, I.A. and T.K., Section 3, A.O. and K.G., Section 4, E.S., Section 5, I.K.N. and T.K., Table 1, A.O. and K.G., writing-review and editing, T.K. and E.S. All authors have read and agreed to the published version of the manuscript.

Funding: This publication is based on work from European Cooperation in Science and Technology (COST) action CA16107 EuroXanth (supported by COST). I.A. was supported by a collaborative agreement between the Namik Kemal University, Tekirdag, Turkey and the University of Modena and Reggio Emilia, Reggio Emilia, Italy. A. Obradović was supported by the Ministry of Education, Science and Technological Development, Republic of Serbia, and Faculty of Agriculture contract No. 451-03-9/2021-14/ 200116. K.G. was funded by the Ministry of Education, Science and Technological Development of the Republic of Serbia, Contract No. 451-03-9/2021-14/200010. T.K. was funded by the PhageFire project, call: H2020-EIC-FTI-2018-2020, project No. 958645.

Institutional Review Board Statement: Not applicable.

Informed Consent Statement: Not applicable.

Data Availability Statement: Not applicable.

Acknowledgments: Alysia Cox is acknowledged for language editing of the manuscript.

Conflicts of Interest: T.K. and I.K.N are employees of Enviroinvest Corp. This does not alter our adherence to MDPI Microorganisms policies on sharing data and materials. The funders had no role in the design of the study; in the collection, analyses, or interpretation of data; in the writing of the manuscript, or in the decision to publish the results.

\section{References}

1. Oerke, E.C. Crop losses to pests. J. Agric. Sci. 2006, 144, 31-34. [CrossRef]

2. Taylor, P.; Reeder, R. Antibiotic use on crops in low and middle-income countries based on recommendations made by agricultural advisors. CABI Agric. Biosci. 2020, 1, 1. [CrossRef]

3. Sundin, G.W.; Castiblanco, L.F.; Yuan, X.; Zeng, Q.; Yang, C.H. Bacterial disease management: Challenges, experience, innovation and future prospects: Challenges in Bacterial Molecular Plant Pathology. Mol. Plant. Pathol. 2016, 17, 1506-1518. [CrossRef]

4. Alengebawy, A.; Abdelkhalek, S.T.; Qureshi, S.R.; Wang, M.Q. Heavy Metals and Pesticides Toxicity in Agricultural Soil and Plants: Ecological Risks and Human Health Implications. Toxics 2021, 9, 42. [CrossRef]

5. Vloek, V.; Pohanka, M. Adsorption of copper in soil and its dependence on physical and chemical properties. Acta Univ. Agric. Silvic. Mendel. Brun. 2018, 66, 219-224. [CrossRef]

6. Wang, L.; Xia, X.; Zhang, W.; Wang, J.; Zhu, L.; Wang, J.; Wei, Z.; Ahmad, Z. Separate and joint eco-toxicological effects of sulfadimidine and copper on soil microbial biomasses and ammoxidation microorganisms abundances. Chemosphere 2019, 228, 556-564. [CrossRef]

7. Sundin, G.W.; Wang, N. Antibiotic Resistance in Plant-Pathogenic Bacteria. Annu. Rev. Phytopathol. 2018, 56, 161-180. [CrossRef]

8. Köhl, J.; Kolnaar, R.; Ravensberg, W.J. Mode of Action of Microbial Biological Control Agents Against Plant Diseases: Relevance Beyond Efficacy. Front. Plant Sci. 2019, 10, 845. [CrossRef] 
9. Svircev, A.; Roach, D.; Castle, A. Framing the Future with Bacteriophages in Agriculture. Viruses 2018, 10, 218. [CrossRef]

10. Hayward, A. The Hosts of Xanthomonas; Springer: Dordrecht, The Netherlands, 1993.

11. Medina, C.A.; Reyes, P.A.; Trujillo, C.A.; Gonzalez, J.L.; Bejarano, D.A.; Montenegro, N.A.; Jacobs, J.M.; Joe, A.; Restrepo, S.; Alfano, J.R.; et al. The role of type III effectors from Xanthomonas axonopodis pv. manihotis in virulence and suppression of plant immunity. Mol. Plant Pathol. 2018, 19, 593-606. [CrossRef]

12. Timilsina, S.; Potnis, N.; Newberry, E.A.; Liyanapathiranage, P.; Iruegas-Bocardo, F.; White, F.F.; Goss, E.M.; Jones, J.B. Xanthomonas diversity, virulence and plant-pathogen interactions. Nat. Rev. Microbiol. 2020, 18, 415-427. [CrossRef]

13. Poplawsky, A.R.; Kawalek, M.D.; Schaad, N. A xanthomonadin-encoding gene cluster for the identification of pathovars of Xanthomonas campestris. Mol. Plant Microbe Interact. 1993, 6, 545. [CrossRef]

14. Midha, S.; Patil, P.B. Genomic insights into the evolutionary origin of Xanthomonas axonopodis pv. citri and its ecological relatives. Appl. Environ. Microbiol. 2014, 80, 6266-6279. [CrossRef]

15. Ferreira, M.A.S.V.; Bonneau, S.; Briand, M.; Cesbron, S.; Portier, P.; Darrasse, A.; Gama, M.A.S.; Barbosa, M.A.G.; Mariano, R.L.R.; Souza, E.B.; et al. Xanthomonas citri pv. viticola affecting grapevine in Brazil: Emergence of a successful monomorphic pathogen. Front. Plant Sci. 2019, 10, 489. [CrossRef] [PubMed]

16. Rademaker, J.L.; Louws, F.J.; Schultz, M.H.; Rossbach, U.; Vauterin, L.; Swings, J.; de Bruijn, F.J. A comprehensive species to strain taxonomic framework for Xanthomonas. Phytopathology 2005, 95, 1098-1111. [CrossRef]

17. Timilsina, S.; Kara, S.; Jacques, M.A.; Potnis, N.; Minsavage, G.V.; Vallad, G.E.; Jones, J.B.; Fischer-Le Saux, M. Reclassification of Xanthomonas gardneri (ex Šutič 1957) Jones et al. 2006 as a later heterotypic synonym of Xanthomonas cynarae Trébaol et al. 2000 and description of X. cynarae pv. cynarae and X. cynarae pv. gardneri based on whole genome analyses. Int. J. Syst. Evol. Microbiol. 2019, 69, 343-349. [CrossRef]

18. Bansal, K.; Kumar, S.; Patil, P.B. Complete Genome Sequence Reveals Evolutionary Dynamics of an Emerging and Variant Pathovar of Xanthomonas euvesicatoria. Genome Biol. Evol. 2018, 10, 3104-3109. [CrossRef]

19. Niño-Liu, D.O.; Ronald, P.C.; Bogdanove, A.J. Xanthomonas oryzae pathovars: Model pathogens of a model crop. Mol. Plant Pathol. 2006, 7, 303-324. [CrossRef] [PubMed]

20. Martins, P.M.M.; de Oliveira Andrade, M.; Benedetti, C.E. Xanthomonas citri subsp. citri: Host interaction and control strategies. Trop. Plant Pathol. 2020, 45, 213-236. [CrossRef]

21. Verdier, V.; López, C.; Bernal, A. Cassava bacterial blight, caused by Xanthomonas axonopodis pv. manihotis. In Cassava in the Third Millennium: Modern Production, Processing, Use, and Marketing Systems; Latin American and Caribbean Consortium to support Cassava Research and Development; Centro Internacional de Agricultura Tropical: Cali Colombia; Technical Centre for Agricultural and Rural Cooperation: Wageningen, The Netherlands , 2012.

22. Altin, I.; Casoli, L.; Stefani, E. First report of bacterial spot caused by Xanthomonas cucurbitae on pumpkin in Italy. New Dis. Rep. 2020, 41, 21. [CrossRef]

23. Bultreys, A.; Gheysen, I. First report of Xanthomonas phaseoli pv.phaseoli and Xanthomonas citri pv. fuscans causing common bacterial blight of bean in Belgium. New Dis. Rep. 2020, 41, 6. [CrossRef]

24. Popović, T.; Menković, J.; Prokić, A.; Obradović, A. First Report of Xanthomonas arboricola pv. pruni Causing Leaf and Fruit Spot on Apricot (Prunus armeniaca L.) in Montenegro. Plant Dis. 2021. [CrossRef]

25. Andrews, J.H. Biological control in the phyllosphere. Annu. Rev. Phytopathol. 1992, 30, 603-635. [CrossRef]

26. Helman, Y.; Chernin, L. Silencing the mob: Disrupting quorum sensing as a means to fight plant disease. Mol. Plant. Pathol. 2015, 16, 316-329. [CrossRef]

27. McNeely, D.; Chanyi, R.M.; Dooley, J.S.; Moore, J.E.; Koval, S.F. Biocontrol of Burkholderia cepacia complex bacteria and bacterial phytopathogens by Bdellovibrio bacteriovorus. Can. J. Microbiol. 2017, 63, 350-358. [CrossRef]

28. Marin, V.R.; Ferrarezi, J.H.; Vieira, G.; Sass, D.C. Recent advances in the biocontrol of Xanthomonas spp. World J. Microbiol. Biotechnol. 2019, 35, 72. [CrossRef]

29. Martínez-Hidalgo, P.; Maymon, M.; Pule-Meulenberg, F.; Hirsch, A.M. Engineering root microbiomes for healthier crops and soils using beneficial, environmentally safe bacteria. Can. J. Microbiol. 2019, 65, 91-104. [CrossRef]

30. Vurukonda, S.S.K.P.; Stefani, E. Endophytic colonization by a streptomycete and a pseudomonad mediated plant growth promotion and enhanced antagonistic activities in tomato plants against Xanthomonas vesicatoria. Can. J. Plant Pathol. 2021, in press.

31. Mushegian, A.R. Are There 10(31) Virus Particles on Earth, or More, or Fewer? J. Bacteriol. 2020, 202. [CrossRef]

32. Clokie, M.R.; Millard, A.D.; Letarov, A.V.; Heaphy, S. Phages in nature. Bacteriophage 2011, 1, 31-45. [CrossRef]

33. Abedon, S.T. Phages, Ecology, Evolution; Cambridge University Press: Cambridge, UK, 2008.

34. Billing, E. Further studies on the phage sensitivity and the determination of phytopathogenic Pseudomonas spp. J. Appl. Bacteriol. 1970, 33, 478-491. [CrossRef]

35. Myung, I.S.; Cho, Y.; Lee, Y.H.; Kwon, H.M. Phage typing and lysotype distribution of Xanthomonas axonopodis pv. citri, the causal agent of citrus bacterial canker in Korea. Plant Pathol. J. 2001, 17, 336-341.

36. Miller, M.; Deiulio, A.; Holland, C.; Douthitt, C.; McMahon, J.; Wiersma-Koch, H.; Turechek, W.W.; D’Elia, T. Complete genome sequence of Xanthomonas phage RiverRider, a novel N4-like bacteriophage that infects the strawberry pathogen Xanthomonas fragariae. Arch. Virol. 2020, 165, 1481-1484. [CrossRef] 
37. Yoshikawa, G.; Askora, A.; Blanc-Mathieu, R.; Kawasaki, T.; Li, Y.; Nakano, M.; Ogata, H.; Yamada, T. Xanthomonas citri jumbo phage XacN1 exhibits a wide host range and high complement of tRNA genes. Sci. Rep. 2018, 8, 4486. [CrossRef]

38. Dong, Z.; Xing, S.; Liu, J.; Tang, X.; Ruan, L.; Sun, M.; Tong, Y.; Peng, D. Isolation and characterization of a novel phage Xoo-sp2 that infects Xanthomonas oryzae pv. oryzae. J. Gen. Virol. 2018, 99, 1453-1462. [CrossRef]

39. Nazir, A.; Dong, Z.; Liu, J.; Tahir, R.A.; Rasheed, M.; Qing, H.; Peng, D.; Tong, Y. Genomic analysis of bacteriophage Xoo-sp13 infecting Xanthomonas oryzae pv. oryzae. Arch. Virol. 2021, 166, 1263-1265. [CrossRef]

40. Nazir, A.; Dong, Z.; Liu, J.; Zhang, X.; Tahir, R.A.; Ashraf, N.; Qing, H.; Peng, D.; Tong, Y. Sequence Analysis of a Jumbo Bacteriophage, Xoo-sp14, That Infects Xanthomonas oryzae pv. oryzae. Microbiol. Resour. Announc. 2020, 9. [CrossRef]

41. Kovacs, T.; Molnar, J.; Varga, I.; Nagy, I.K.; Valappil, S.K.; Papp, S.; Vera Cruz, C.M.; Oliva, R.; Vizi, T.; Schneider, G.; et al. Complete Genome Sequences of 10 Xanthomonas oryzae pv. oryzae Bacteriophages. Microbiol. Resour. Announc. 2019, 8. [CrossRef]

42. Papaianni, M.; Ricciardelli, A.; Fulgione, A.; d’Errico, G.; Zoina, A.; Lorito, M.; Woo, S.L.; Vinale, F.; Capparelli, R. Antibiofilm Activity of a Trichoderma Metabolite against Xanthomonas campestris pv. campestris, Alone and in Association with a Phage. Microorganisms 2020, 8, 620. [CrossRef]

43. Papaianni, M.; Paris, D.; Woo, S.L.; Fulgione, A.; Rigano, M.M.; Parrilli, E.; Tutino, M.L.; Marra, R.; Manganiello, G.; Casillo, A.; et al. Plant Dynamic Metabolic Response to Bacteriophage Treatment After Xanthomonas campestris pv. campestris Infection. Front Microbiol. 2020, 11, 732. [CrossRef]

44. Bhoyar, M.S.; Singh, U.B.; Sahu, U.; Nagrale, D.T.; Sahu, P.K. Characterization of lytic bacteriophage XCC9SH3 infecting Xanthomonas campestris pv. campestris. J. Plant Pathol. 2017, 99, 233-238.

45. da Silva, F.P.; Xavier, A.D.S.; Bruckner, F.P.; de Rezende, R.R.; Vidigal, P.M.P.; Alfenas-Zerbini, P. Biological and molecular characterization of a bacteriophage infecting Xanthomonas campestris pv. campestris, isolated from brassica fields. Arch. Virol. 2019, 164, 1857-1862. [CrossRef] [PubMed]

46. Domotor, D.; Frank, T.; Rakhely, G.; Doffkay, Z.; Schneider, G.; Kovacs, T. Comparative analysis of two bacteriophages of Xanthomonas arboricola pv. juglandis. Infect. Genet. Evol. 2016, 43, 371-377. [CrossRef] [PubMed]

47. Retamales, J.; Vasquez, I.; Santos, L.; Segovia, C.; Ayala, M.; Alvarado, R.; Nunez, P.; Santander, J. Complete Genome Sequences of Lytic Bacteriophages of Xanthomonas arboricola pv. juglandis. Genome Announc. 2016, 4. [CrossRef]

48. Solis-Sanchez, G.A.; Quinones-Aguilar, E.E.; Fraire-Velazquez, S.; Vega-Arreguin, J.; Rincon-Enriquez, G. Complete Genome Sequence of XaF13, a Novel Bacteriophage of Xanthomonas vesicatoria from Mexico. Microbiol. Resour. Announc. 2020, 9. [CrossRef]

49. Rios-Sandoval, M.; Quinones-Aguilar, E.E.; Solis-Sanchez, G.A.; Enriquez-Vara, J.N.; Rincon-Enriquez, G. Complete Genome Sequence of Xanthomonas vesicatoria Bacteriophage PhiXaF18, a Contribution to the Biocontrol of Bacterial Spot of Pepper in Mexico. Microbiol. Resour. Announc. 2020, 9. [CrossRef]

50. Edwards, J.; Johnson, C.; Santos-Medellín, C.; Lurie, E.; Podishetty, N.K.; Bhatnagar, S.; Eisen, J.A.; Sundaresan, V. Structure, variation, and assembly of the root-associated microbiomes of rice. Proc. Natl. Acad. Sci. USA 2015, 112, E911-E920. [CrossRef]

51. Zhao, Y.; Damicone, J.P.; Bender, C.L. Detection, Survival, and Sources of Inoculum for Bacterial Diseases of Leafy Crucifers in Oklahoma. Plant Dis. 2002, 86, 883-888. [CrossRef]

52. Bulgarelli, D.; Garrido-Oter, R.; Munch, P.C.; Weiman, A.; Droge, J.; Pan, Y.; McHardy, A.C.; Schulze-Lefert, P. Structure and function of the bacterial root microbiota in wild and domesticated barley. Cell Host Microbe 2015, 17, 392-403. [CrossRef]

53. Taulé, C.; Vaz-Jauri, P.; Battistoni, F. Insights into the early stages of plant-endophytic bacteria interaction. World J. Microbiol. Biotechnol. 2021, 37, 13. [CrossRef]

54. Petrocelli, S.; Tondo, M.L.; Daurelio, L.D.; Orellano, E.G. Modifications of Xanthomonas axonopodis pv. citri lipopolysaccharide affect the basal response and the virulence process during citrus canker. PLoS ONE 2012, 7, e40051. [CrossRef]

55. Pradhan, B.B.; Ranjan, M.; Chatterjee, S. XadM, a novel adhesin of Xanthomonas oryzae pv. oryzae, exhibits similarity to Rhs family proteins and is required for optimum attachment, biofilm formation, and virulence. Mol. Plant. Microbe Interact. 2012, 25, 1157-1170. [CrossRef]

56. Dunger, G.; Guzzo, C.R.; Andrade, M.O.; Jones, J.B.; Farah, C.S. Xanthomonas citri subsp. citri type IV Pilus is required for twitching motility, biofilm development, and adherence. Mol. Plant. Microbe Interact. 2014, 27, 1132-1147. [CrossRef]

57. Petrocelli, S.; Arana, M.R.; Cabrini, M.N.; Casabuono, A.C.; Moyano, L.; Beltramino, M.; Moreira, L.M.; Couto, A.S.; Orellano, E.G. Deletion of pilA, a Minor Pilin-Like Gene, from Xanthomonas citri subsp. citri Influences Bacterial Physiology and Pathogenesis. Curr. Microbiol. 2016, 73, 904-914. [CrossRef]

58. An, S.Q.; Potnis, N.; Dow, M.; Vorholter, F.J.; He, Y.Q.; Becker, A.; Teper, D.; Li, Y.; Wang, N.; Bleris, L.; et al. Mechanistic insights into host adaptation, virulence and epidemiology of the phytopathogen Xanthomonas. FEMS Microbiol. Rev. 2020, 44, 1-32. [CrossRef] [PubMed]

59. Bostock, R.M.; Pye, M.F.; Roubtsova, T.V. Predisposition in plant disease: Exploiting the nexus in abiotic and biotic stress perception and response. Annu. Rev. Phytopathol. 2014, 52, 517-549. [CrossRef]

60. Boller, T.; He, S.Y. Innate immunity in plants: An arms race between pattern recognition receptors in plants and effectors in microbial pathogens. Science 2009, 324, 742-744. [CrossRef] [PubMed]

61. Návarová, H.; Bernsdorff, F.; Döring, A.C.; Zeier, J. Pipecolic acid, an endogenous mediator of defense amplification and priming, is a critical regulator of inducible plant immunity. Plant Cell 2012, 24, 5123-5141. [CrossRef]

62. Shah, J.; Chaturvedi, R.; Chowdhury, Z.; Venables, B.; Petros, R.A. Signaling by small metabolites in systemic acquired resistance. Plant J. 2014, 79, 645-658. [CrossRef] 
63. Schwachtje, J.; Fischer, A.; Erban, A.; Kopka, J. Primed primary metabolism in systemic leaves: A functional systems analysis. Sci. Rep. 2018, 8, 216. [CrossRef] [PubMed]

64. Koczan, J.M.; Lenneman, B.R.; McGrath, M.J.; Sundin, G.W. Cell surface attachment structures contribute to biofilm formation and xylem colonization by Erwinia amylovora. Appl. Environ. Microbiol. 2011, 77, 7031-7039. [CrossRef] [PubMed]

65. Yu, X.; Lund, S.P.; Scott, R.A.; Greenwald, J.W.; Records, A.H.; Nettleton, D.; Lindow, S.E.; Gross, D.C.; Beattie, G.A. Transcriptional responses of Pseudomonas syringae to growth in epiphytic versus apoplastic leaf sites. Proc. Natl. Acad. Sci. USA 2013, 110, E425-E434. [CrossRef] [PubMed]

66. Li, J.; Wang, N. Foliar application of biofilm formation-inhibiting compounds enhances control of citrus canker caused by Xanthomonas citri subsp. citri. Phytopathology 2014, 104, 134-142. [CrossRef] [PubMed]

67. Stoodley, P.; Sauer, K.; Davies, D.G.; Costerton, J.W. Biofilms as complex differentiated communities. Annu. Rev. Microbiol. 2002, 56, 187-209. [CrossRef]

68. Sutherland, I.W. The biofilm matrix-an immobilized but dynamic microbial environment. Trends Microbiol. 2001, 9, $222-227$. [CrossRef]

69. Branda, S.S.; Vik, S.; Friedman, L.; Kolter, R. Biofilms: The matrix revisited. Trends Microbiol. 2005, 13, 20-26. [CrossRef]

70. Vojnov, A.A.; Slater, H.; Daniels, M.J.; Dow, J.M. Expression of the gum operon directing xanthan biosynthesis in Xanthomonas campestris and its regulation in planta. Mol. Plant Microbe Interact. 2001, 14, 768-774. [CrossRef] [PubMed]

71. Vojnov, A.A.; Zorreguieta, A.; Dow, J.M.; Daniels, M.J.; Dankert, M.A. Evidence for a role for the gumB and gumC gene products in the formation of xanthan from its pentasaccharide repeating unit by Xanthomonas campestris. Microbiology 1998, 144 Pt 6, 1487-1493. [CrossRef]

72. Dunger, G.; Relling, V.M.; Tondo, M.L.; Barreras, M.; Ielpi, L.; Orellano, E.G.; Ottado, J. Xanthan is not essential for pathogenicity in citrus canker but contributes to Xanthomonas epiphytic survival. Arch. Microbiol. 2007, 188, 127-135. [CrossRef]

73. Rigano, L.A.; Siciliano, F.; Enrique, R.; Sendin, L.; Filippone, P.; Torres, P.S.; Questa, J.; Dow, J.M.; Castagnaro, A.P.; Vojnov, A.A.; et al. Biofilm formation, epiphytic fitness, and canker development in Xanthomonas axonopodis pv. citri. Mol. Plant Microbe Interact. 2007, 20, 1222-1230. [CrossRef] [PubMed]

74. Fonseca, N.P.; Patane, J.S.L.; Varani, A.M.; Felestrino, E.B.; Caneschi, W.L.; Sanchez, A.B.; Cordeiro, I.F.; Lemes, C.G.C.; Assis, R.A.B.; Garcia, C.C.M.; et al. Analyses of Seven New Genomes of Xanthomonas citri pv. aurantifolii Strains, Causative Agents of Citrus Canker B and C, Show a Reduced Repertoire of Pathogenicity-Related Genes. Front. Microbiol. 2019, $10,2361$. [CrossRef]

75. Chou, F.L.; Chou, H.C.; Lin, Y.S.; Yang, B.Y.; Lin, N.T.; Weng, S.F.; Tseng, Y.H. The Xanthomonas campestris gumD gene required for synthesis of xanthan gum is involved in normal pigmentation and virulence in causing black rot. Biochem. Biophys. Res. Commun. 1997, 233, 265-269. [CrossRef]

76. Katzen, F.; Ferreiro, D.U.; Oddo, C.G.; Ielmini, M.V.; Becker, A.; Pühler, A.; Ielpi, L. Xanthomonas campestris pv. campestris gum mutants: Effects on xanthan biosynthesis and plant virulence. J. Bacteriol. 1998, 180, 1607-1617. [CrossRef] [PubMed]

77. Dharmapuri, S.; Sonti, R.V. A transposon insertion in the gumG homologue of Xanthomonas oryzae pv.oryzae causes loss of extracellular polysaccharide production and virulence. FEMS Microbiol. Lett. 1999, 179, 53-59. [CrossRef] [PubMed]

78. Kemp, B.P.; Horne, J.; Bryant, A.; Cooper, R.M. Xanthomonas axonopodis pv. manihotis gumD gene is essential for EPS production and pathogenicity and enhances epiphytic survival on cassava (Manihot esculenta). Physiol. Mol. Plant. Pathol. 2004, 64, 209-218.

79. Dow, J.M.; Crossman, L.; Findlay, K.; He, Y.Q.; Feng, J.X.; Tang, J.L. Biofilm dispersal in Xanthomonas campestris is controlled by cell-cell signaling and is required for full virulence to plants. Proc. Natl. Acad. Sci. USA 2003, 100, 10995-11000. [CrossRef] [PubMed]

80. Martins, P.M.M.; Merfa, M.V.; Takita, M.A.; De Souza, A.A. Persistence in Phytopathogenic Bacteria: Do We Know Enough? Front. Microbiol. 2018, 9, 1099. [CrossRef]

81. Ghezzi, J.I.; Steck, T.R. Induction of the viable but non-culturable condition in Xanthomonas campestris pv. campestris in liquid microcosms and sterile soil. FEMS Microbiol. Ecol. 1999, 30, 203-208. [CrossRef]

82. Martins, P.M.M.; Wood, T.K.; de Souza, A.A. Persister Cells Form in the Plant Pathogen Xanthomonas citri subsp. citri under Different Stress Conditions. Microorganisms 2021, 9, 384. [CrossRef]

83. Harper, D.R.; Parracho, H.M.R.T.; Walker, J.; Sharp, R.; Hughes, G.; Werthen, M.; Lehman, S.; Morales, S. Bacteriophages and Biofilms. Antibiotics 2014, 3, 270-2884. [CrossRef]

84. Dow, M.; Newman, M.A.; von Roepenack, E. The Induction and Modulation of Plant Defense Responses by Bacterial Lipopolysaccharides. Annu. Rev. Phytopathol. 2000, 38, 241-261. [CrossRef] [PubMed]

85. Meyer, A.; Pühler, A.; Niehaus, K. The lipopolysaccharides of the phytopathogen Xanthomonas campestris pv. campestris induce an oxidative burst reaction in cell cultures of Nicotiana tabacum. Planta 2001, 213, 214-222. [CrossRef]

86. Kingsley, M.T.; Gabriel, D.W.; Marlow, G.C.; Roberts, P.D. The opsX locus of Xanthomonas campestris affects host range and biosynthesis of lipopolysaccharide and extracellular polysaccharide. J. Bacteriol. 1993, 175, 5839-5850. [CrossRef]

87. Dow, J.M.; Osbourn, A.E.; Wilson, T.J.; Daniels, M.J. A locus determining pathogenicity of Xanthomonas campestris is involved in lipopolysaccharide biosynthesis. Mol. Plant. Microbe Interact. 1995, 8, 768-777. [CrossRef]

88. Newman, M.A.; Dow, J.M.; Daniels, M.J. Bacterial lipopolysaccharides and plant-pathogen interactions. Eur. J. Plant Pathol. 2001, 107, 95-102. [CrossRef] 
89. Gerlach, R.G.; Hensel, M. Protein secretion systems and adhesins: The molecular armory of Gram-negative pathogens. Int. J. Med. Microbiol. 2007, 297, 401-415. [CrossRef]

90. Yang, X.; Long, M.; Shen, X. Effector-Immunity Pairs Provide the T6SS Nanomachine its Offensive and Defensive Capabilities. Molecules 2018, 23, 1009. [CrossRef]

91. Boch, J.; Scholze, H.; Schornack, S.; Landgraf, A.; Hahn, S.; Kay, S.; Lahaye, T.; Nickstadt, A.; Bonas, U. Breaking the code of DNA binding specificity of TAL-type III effectors. Science 2009, 326, 1509-1512. [CrossRef] [PubMed]

92. Lang, J.M.; Perez-Quintero, A.L.; Koebnik, R.; DuCharme, E.; Sarra, S.; Doucoure, H.; Keita, I.; Ziegle, J.; Jacobs, J.M.; Oliva, R.; et al. A Pathovar of Xanthomonas oryzae Infecting Wild Grasses Provides Insight Into the Evolution of Pathogenicity in Rice Agroecosystems. Front Plant. Sci. 2019, 10, 507. [CrossRef] [PubMed]

93. Ruh, M.; Briand, M.; Bonneau, S.; Jacques, M.A.; Chen, N.W.G. Xanthomonas adaptation to common bean is associated with horizontal transfers of genes encoding TAL effectors. BMC Genom. 2017, 18, 670. [CrossRef] [PubMed]

94. Dennehy, J.J.; Abedon, S.T. Bacteriophage Ecology. In Bacteriophages; Harper, D.R., Abedon, S.T., Burrowes, B.H., McConville, M.L., Eds.; Springer Nature: Cham, Switzerland, 2021; pp. 253-294.

95. Born, Y.; Fieseler, L.; Klumpp, J.; Eugster, M.R.; Zurfluh, K.; Duffy, B.; Loessner, M.J. The tail-associated depolymerase of Erwinia amylovora phage L1 mediates host cell adsorption and enzymatic capsule removal, which can enhance infection by other phage. Environ. Microbiol. 2014, 16, 2168-2180. [CrossRef] [PubMed]

96. Hargreaves, K.R.; Kropinski, A.M.; Clokie, M.R. What does the talking?: Quorum sensing signalling genes discovered in a bacteriophage genome. PLoS ONE 2014, 9, e85131. [CrossRef]

97. Silpe, J.E.; Bassler, B.L. A Host-Produced Quorum-Sensing Autoinducer Controls a Phage Lysis-Lysogeny Decision. Cell 2019, 176, 268.e13-280.e13. [CrossRef] [PubMed]

98. He, Y.W.; Zhang, L.H. Quorum sensing and virulence regulation in Xanthomonas campestris. FEMS Microbiol. Rev. 2008, 32, 842-857. [CrossRef]

99. Konopka, A.; Lindemann, S.; Fredrickson, J. Dynamics in microbial communities: Unraveling mechanisms to identify principles. ISME J. 2015, 9, 1488-1495. [CrossRef]

100. Louca, S.; Doebeli, M. Taxonomic variability and functional stability in microbial communities infected by phages. Environ. Microbiol. 2017, 19, 3863-3878. [CrossRef]

101. Braga, L.P.; Soucy, S.M.; Amgarten, D.E.; da Silva, A.M.; Setubal, J.C. Bacterial Diversification in the Light of the Interactions with Phages: The Genetic Symbionts and Their Role in Ecological Speciation. Front. Ecol. Evol. 2018, 6. [CrossRef]

102. Molnar, J.; Magyar, B.; Schneider, G.; Laczi, K.; Valappil, S.K.; Kovacs, A.L.; Nagy, I.K.; Rakhely, G.; Kovacs, T. Identification of a novel archaea virus, detected in hydrocarbon polluted Hungarian and Canadian samples. PLoS ONE 2020, 15, e0231864. [CrossRef]

103. Blount, Z.D.; Borland, C.Z.; Lenski, R.E. Historical contingency and the evolution of a key innovation in an experimental population of Escherichia coli. Proc. Natl. Acad. Sci. USA 2008, 105, 7899-7906. [CrossRef]

104. Hulin, M.T.; Armitage, A.D.; Vicente, J.G.; Holub, E.B.; Baxter, L.; Bates, H.J.; Mansfield, J.W.; Jackson, R.W.; Harrison, R.J. Comparative genomics of Pseudomonas syringae reveals convergent gene gain and loss associated with specialization onto cherry (Prunus avium). New Phytol. 2018, 219, 672-696. [CrossRef]

105. Zhang, H.L.; Ntambo, M.S.; Rott, P.C.; Chen, G.; Chen, L.L.; Huang, M.T.; Gao, S.J. Complete Genome Sequence Reveals Evolutionary and Comparative Genomic Features of Xanthomonas albilineans Causing Sugarcane Leaf Scald. Microorganisms 2020, 8, 182. [CrossRef]

106. Labrie, S.J.; Samson, J.E.; Moineau, S. Bacteriophage resistance mechanisms. Nat. Rev. Microbiol. 2010, 8, 317-327. [CrossRef] [PubMed]

107. Weiss, B.D.; Capage, M.A.; Kessel, M.; Benson, S.A. Isolation and characterization of a generalized transducing phage for Xanthomonas campestris pv. campestris. J. Bacteriol. 1994, 176, 3354-3359. [CrossRef] [PubMed]

108. Newberry, E.A.; Bhandari, R.; Minsavage, G.V.; Timilsina, S.; Jibrin, M.O.; Kemble, J.; Sikora, E.J.; Jones, J.B.; Potnis, N. Independent Evolution with the Gene Flux Originating from Multiple Xanthomonas Species Explains Genomic Heterogeneity in Xanthomonas perforans. Appl. Environ. Microbiol. 2019, 85. [CrossRef] [PubMed]

109. Bartoli, C.; Roux, F.; Lamichhane, J.R. Molecular mechanisms underlying the emergence of bacterial pathogens: An ecological perspective. Mol. Plant Pathol. 2016, 17, 303-310. [CrossRef] [PubMed]

110. Lima, W.C.; Paquola, A.C.; Varani, A.M.; Van Sluys, M.A.; Menck, C.F. Laterally transferred genomic islands in Xanthomonadales related to pathogenicity and primary metabolism. FEMS Microbiol. Lett. 2008, 281, 87-97. [CrossRef] [PubMed]

111. da Silva, A.C.; Ferro, J.A.; Reinach, F.C.; Farah, C.S.; Furlan, L.R.; Quaggio, R.B.; Monteiro-Vitorello, C.B.; Van Sluys, M.A.; Almeida, N.F.; Alves, L.M.; et al. Comparison of the genomes of two Xanthomonas pathogens with differing host specificities. Nature 2002, 417, 459-463. [CrossRef]

112. Liang, X.; Wagner, R.E.; Li, B.; Zhang, N.; Radosevich, M. Quorum Sensing Signals Alter in vitro Soil Virus Abundance and Bacterial Community Composition. Front Microbiol. 2020, 11, 1287. [CrossRef]

113. Ghosh, D.; Roy, K.; Williamson, K.E.; Srinivasiah, S.; Wommack, K.E.; Radosevich, M. Acyl-homoserine lactones can induce virus production in lysogenic bacteria: An alternative paradigm for prophage induction. Appl. Environ. Microbiol. 2009, 75, 7142-7152. [CrossRef] [PubMed] 
114. Erez, Z.; Steinberger-Levy, I.; Shamir, M.; Doron, S.; Stokar-Avihail, A.; Peleg, Y.; Melamed, S.; Leavitt, A.; Savidor, A.; Albeck, S.; et al. Communication between viruses guides lysis-lysogeny decisions. Nature 2017, 541, 488-493. [CrossRef]

115. Stokar-Avihail, A.; Tal, N.; Erez, Z.; Lopatina, A.; Sorek, R. Widespread Utilization of Peptide Communication in Phages Infecting Soil and Pathogenic Bacteria. Cell Host Microbe 2019, 25, 746-755.e745. [CrossRef] [PubMed]

116. Wiggins, B.A.; Alexander, M. Minimum bacterial density for bacteriophage replication: Implications for significance of bacteriophages in natural ecosystems. Appl. Environ. Microbiol. 1985, 49, 19-23. [CrossRef] [PubMed]

117. Adhikari, N.; Acharya, K.P. Effectiveness of Bacteriophage Therapy in Field Conditions and Possible Future Applications. Curr. Pharm. Biotechnol. 2020, 21, 364-373. [CrossRef] [PubMed]

118. Hung, C.H.; Wu, H.C.; Tseng, Y.H. Mutation in the Xanthomonas campestris xanA gene required for synthesis of xanthan and lipopolysaccharide drastically reduces the efficiency of bacteriophage (phi)L7 adsorption. Biochem. Biophys. Res. Commun. 2002, 291, 338-343. [CrossRef]

119. Oechslin, F. Resistance Development to Bacteriophages Occurring during Bacteriophage Therapy. Viruses 2018, 10. [CrossRef]

120. Torres-Barcelo, C. The disparate effects of bacteriophages on antibiotic-resistant bacteria. Emerg. Microbes Infect. 2018, 7, 168. [CrossRef]

121. Bertozzi Silva, J.; Storms, Z.; Sauvageau, D. Host receptors for bacteriophage adsorption. FEMS Microbiol. Lett. $2016,363$. [CrossRef]

122. Bondy-Denomy, J.; Pawluk, A.; Maxwell, K.L.; Davidson, A.R. Bacteriophage genes that inactivate the CRISPR/Cas bacterial immune system. Nature 2013, 493, 429-432. [CrossRef]

123. Seed, K.D.; Lazinski, D.W.; Calderwood, S.B.; Camilli, A. A bacteriophage encodes its own CRISPR/Cas adaptive response to evade host innate immunity. Nature 2013, 494, 489-491. [CrossRef]

124. Ahmad, A.A.; Askora, A.; Kawasaki, T.; Fujie, M.; Yamada, T. The filamentous phage XacF1 causes loss of virulence in Xanthomonas axonopodis pv. citri, the causative agent of citrus canker disease. Front Microbiol. 2014, 5, 321. [CrossRef] [PubMed]

125. Borah, P.; Jindal, J.; Verma, J. Integrated management of bacterial leaf spot of mungbean with bacteriophages of Xav and chemicals. J. Mycol. Plant Pathol. 2000, 30, 19-21.

126. Mallmann, W.; Hemstreest, C. Isolation of an inhibitory substance from plants. Agric. Res. 1924, 28, 599-602.

127. Civerolo, E.L.; Keil, H.L. Inhibition of bacterial spot of peach foliage by Xanthomonas pruni bacteriophage. Phytopathology 1969, 59, 1966-1967.

128. Civerolo, E.L. Relationship of Xanthomonas pruni bacteriophages to bacterial spot disease in Prunus. Phytopathology 1973, 63, 1279-1284. [CrossRef]

129. Zaccardelli, M.; Saccardi, A.; Gambin, E.; Mazzucchi, U. Xanthomonas campestris pv. pruni bacteriophages on peach trees and their potential use for biological control. Phytopathol. Mediterr. 1992, 31, 133-140.

130. Saccardi, A.; Gambin, E.; Zaccardelli, M.; Barone, G.; Mazzucchi, U. Xanthomonas campestris pv. pruni control trials with phage treatments on peaches in the orchard. Phytopathol. Mediterr. 1993, 32, $206-210$.

131. Flaherty, J.E.; Jones, J.B.; Harbaugh, B.K.; Somodi, G.C.; Jackson, L.E. Control of bacterial spot on tomato in the greenhouse and field with H-mutant bacteriophages. HortScience 2000, 35, 882-884. [CrossRef]

132. Balogh, B. Strategies of Improving the Efficacy of Bacteriophages for Controlling Bacterial Spot of Tomato; University of Florida: Gainesville, FL, USA, 2002.

133. Balogh, B.; Jones, J.B.; Momol, M.T.; Olson, S.M.; Obradovic, A.; King, P.; Jackson, L.E. Improved Efficacy of Newly Formulated Bacteriophages for Management of Bacterial Spot on Tomato. Plant Dis. 2003, 87, 949-954. [CrossRef]

134. Balogh, B.; Jones, J.B.; Momol, M.T.; Olson, M. S. Persistence of bacteriophages as biocontrol agents in the tomato canopy. Acta Hortic. 2005, 695, 299-302. [CrossRef]

135. Obradovic, A.; Jones, J.B.; Momol, M.T.; Balogh, B.; Olson, S.M. Management of Tomato Bacterial Spot in the Field by Foliar Applications of Bacteriophages and SAR Inducers. Plant Dis. 2004, 88, 736-740. [CrossRef]

136. Obradovic, A.; Jones, J.B.; Momol, M.T.; Olson, S.M.; Jackson, L.E.; Balogh, B.; Guven, K.; Iriarte, F.B. Integration of Biological Control Agents and Systemic Acquired Resistance Inducers Against Bacterial Spot on Tomato. Plant Dis. 2005, 89, 712-716. [CrossRef]

137. Jones, J.B.; Momol, M.T.; Obradovic, A.; Balogh, B.; Olson, S.M. Bacterial spot management on tomatoes. Acta Hortic 2005, 695, 119-124. [CrossRef]

138. Jones, J.B.; Jackson, L.E.; Balogh, B.; Obradovic, A.; Iriarte, F.B.; Momol, M.T. Bacteriophages for plant disease control. Annu. Rev. Phytopathol. 2007, 45, 245-262. [CrossRef]

139. Obradovic, A.; Jones, J.B.; Balogh, B.; Momol, M.T. Integrated management of tomato bacterial spot. In Integrated Management of Plant Diseases Caused by Fungi, Phytoplasma and Bacteria; Ciancio, A., Mukerji, K.G., Eds.; Springer Science + Business Media B. V.: Berlin/Heidleberg, Germany, 2008; pp. 211-223.

140. Abrahamian, P.; Jones, J.B.; Vallad, G.E. Efficacy of copper and copper alternatives for management of bacterial spot on tomato under transplant and field production. Crop. Prot. 2019, 126, 104919. [CrossRef]

141. Gašić, K.; Kuzmanović, N.; Ivanović, M.; Prokić, A.; Šević, M.; Obradović, A. Complete Genome of the Xanthomonas euvesicatoria Specific Bacteriophage KФ1, Its Survival and Potential in Control of Pepper Bacterial Spot. Front Microbiol. 2018, 9, 2021. [CrossRef] 
142. Šević, M.; Gašić, K.; Ignjatov, M.; Mijatović, M.; Prokić, A.; Obradovic, A. Integration of biological and conventional treatments in control of pepper bacterial spot. Crop. Prot. 2019, 119, 46-51. [CrossRef]

143. Lang, J.M.; Gent, D.H.; Schwartz, H.F. Management of Xanthomonas Leaf Blight of Onion with Bacteriophages and a Plant Activator. Plant Dis. 2007, 91, 871-878. [CrossRef] [PubMed]

144. Balogh, B. Characterization and Use of Bacteriophages Associated with Citrus Bacterial Pathogens for Disease Control; University of Florida: Gainesville, FL, USA, 2006.

145. Balogh, B.; Canteros, B.I.; Stall, R.E.; Jones, J.B. Control of Citrus Canker and Citrus Bacterial Spot with Bacteriophages. Plant Dis. 2008, 92, 1048-1052. [CrossRef]

146. Ibrahim, Y.E.; Saleh, A.A.; Al-Saleh, M.A. Management of Asiatic Citrus Canker Under Field Conditions in Saudi Arabia Using Bacteriophages and Acibenzolar-S-Methyl. Plant Dis. 2017, 101, 761-765. [CrossRef] [PubMed]

147. Kuo, T.T.; Chang, L.C.; Yang, C.M.; Yang, S. E. Bacterial leaf blight of rice plant IV. Effect of bacteriophage on the infectivity of Xanthomonas oryzae. Bot. Bull. Acad. Sin. 1971, 12,1-9.

148. Chae, J.C.; Hung, N.B.; Yu, S.M.; Lee, H.K.; Lee, Y.H. Diversity of bacteriophages infecting Xanthomonas oryzae pv. oryzae in paddy fields and its potential to control bacterial leaf blight of rice. J. Microbiol. Biotechnol. 2014, 24, 740-747. [CrossRef] [PubMed]

149. Ogunyemi, S.O.; Chen, J.; Zhang, M.; Wang, L.; Masum, M.M.I.; Yan, C.; An, Q.; Li, B.; Chen, J. Identification and characterization of five new OP2-related Myoviridae bacteriophages infecting different strains of Xanthomonas oryzae pv. oryzae. J. Plant Pathol. 2019, 101, 263-273. [CrossRef]

150. Flaherty, J.E.; Harbaugh, B.K.; Jones, J.B.; Somodi, G.C.; Jackson, L.E. H-mutant bacteriophages as a potential biocontrol of bacterial blight of geranium. HortScience 2001, 36, 98-100. [CrossRef]

151. Nagai, H.; Miyake, N.; Kato, S.; Maekawa, D.; Inoue, Y.; Takikawa, Y. Improved control of black rot of broccoli caused by Xanthomonas campestris pv. campestris using a bacteriophage and a nonpathogenic Xanthomonas sp. strain. J. Gen. Plant Pathol. 2017, 83, 373-381.

152. Orynbayev, A.; Dzhalilov, F.; Ignatov, A. Improved efficacy of formulated bacteriophage in control of black rot caused by Xanthomonas campestris pv. campestris on cabbage seedlings. Arch. Phytopathol. Plant Prot. 2020, 379-394. [CrossRef]

153. Greer, G.G. Bacteriophage control of foodborne bacteriat. J. Food Prot. 2005, 68, 1102-1111. [CrossRef]

154. Liu, N.; Lewis, C.; Zheng, W.; Fu, Z.Q. Phage Cocktail Therapy: Multiple Ways to Suppress Pathogenicity. Trends Plant. Sci. 2020, 25, 315-317. [CrossRef]

155. Hathaway, H.; Ajuebor, J.; Stephens, L.; Coffey, A.; Potter, U.; Sutton, J.M.; Jenkins, A.T. Thermally triggered release of the bacteriophage endolysin CHAP. J. Control Release 2017, 245, 108-115. [CrossRef] [PubMed]

156. Leverentz, B.; Conway, W.S.; Alavidze, Z.; Janisiewicz, W.J.; Fuchs, Y.; Camp, M.J.; Chighladze, E.; Sulakvelidze, A. Examination of bacteriophage as a biocontrol method for Salmonella on fresh-cut fruit: A model study. J. Food Prot. 2001, 64, 1116-1121. [CrossRef]

157. Obradović, A.; Jones, J.B.; Balogh, B.; Gašić, K. Considerations for Using Bacteriophages in Plant Pathosystems. In Bacterial Viruses: Exploitation for Biocontrol and Therapeutics; Coffey, A., Colin, B., Eds.; Caister Academic Press: Wymondham, UK, 2020; pp. 257-282.

158. Balogh, B.; Nga, N.T.T.; Jones, J.B. Relative Level of Bacteriophage Multiplication in vitro or in Phyllosphere May Not Predict in planta Efficacy for Controlling Bacterial Leaf Spot on Tomato Caused by Xanthomonas perforans. Front. Microbiol. 2018, 9, 2176. [CrossRef]

159. Gill, J.; Abedon, S.T. Bacteriophage Ecology and Plants. APS Feature 2003. [CrossRef]

160. Iriarte, F.B.; Balogh, B.; Momol, M.T.; Smith, L.M.; Wilson, M.; Jones, J.B. Factors affecting survival of bacteriophage on tomato leaf surfaces. Appl. Environ. Microbiol. 2007, 73, 1704-1711. [CrossRef]

161. erwiphage.hu. Available online: https:/ / www.erwiphage.com/okologiai-termesztes/ (accessed on 13 May 2021).

162. Storey, M.V.; Ashbolt, N.J. Persistence of two model enteric viruses (B40-8 and MS-2 bacteriophages) in water distribution pipe biofilms. Water Sci. Technol. 2001, 43, 133-138. [CrossRef]

163. Williams, S.T.; Mortimer, A.M.; Manchester, L. Ecology of soil bacteriophages. In Phage Ecology; Goyal, S.M., Gerba, C.P., Bitton, G., Eds.; John Wiley and Sons: New York, NY, USA, 1987; pp. 157-179.

164. Sykes, I.K.; Lanning, S.; Williams, S.T. The effect of pH on soil actinophage. J. Gen. Microbiol. 1981, 122, 271-280. [CrossRef]

165. Bae, J.Y.; Wu, J.; Lee, H.J.; Jo, E.J.; Murugaiyan, S.; Chung, E.; Lee, S.W. Biocontrol potential of a lytic bacteriophage PE204 against bacterial wilt of tomato. J. Microbiol. Biotechnol. 2012, 22, 1613-1620. [CrossRef] [PubMed]

166. Fujiwara, A.; Fujisawa, M.; Hamasaki, R.; Kawasaki, T.; Fujie, M.; Yamada, T. Biocontrol of Ralstonia solanacearum by treatment with lytic bacteriophages. Appl. Environ. Microbiol. 2011, 77, 4155-4162. [CrossRef] [PubMed]

167. Forti, F.; Roach, D.R.; Cafora, M.; Pasini, M.E.; Horner, D.S.; Fiscarelli, E.V.; Rossitto, M.; Cariani, L.; Briani, F.; Debarbieux, L.; et al. Design of a Broad-Range Bacteriophage Cocktail That Reduces Pseudomonas aeruginosa Biofilms and Treats Acute Infections in Two Animal Models. Antimicrob. Agents Chemother. 2018, 62. [CrossRef] [PubMed]

168. Merabishvili, M.; Pirnay, J.P.; De Vos, D. Guidelines to Compose an Ideal Bacteriophage Cocktail. Methods Mol. Biol. 2018, 1693, 99-110. [CrossRef] [PubMed]

169. Jackson, L.E. Bacteriophage Prevention and Control of Harmful Plant Bacteria. U.S. Patent 4828999, 9 May 1989.

170. Ehlers, R.U. Regulation of Biological Control Agents; Springer: Dresden, Germany, 2011. 
171. Stefani, E. Biosafety and agro-environmental concerns related to the use of bacterial biocontrol agents in crop protection. J. Plant. Pathol. 2016, 98 (Suppl. 4), 31-32.

172. EFSA. Scientic opinion on the update of the list of QPS-recommended biological agents intentionally added to food or feed as notied to EFSA (2017-2019). EFSA J. 2020, 18, 56. [CrossRef]

173. Holtappels, D.; Lavigne, R.; Huys, I.; Wagemans, J. Protection of Phage Applications in Crop Production: A Patent Landscape. Viruses 2019, 11, 277. [CrossRef]

174. European Commission. Regulation (EC) No 1107/2009 of the European Parliament and of the Council of 21 October 2009 concerning the placing of plant protection products on the market and repealing Council Directives 79/117/EEC and 91/414/EEC. Off. J. Eur. Union 2009, 52, 1-50.

175. Muniesa, M.; Colomer-Lluch, M.; Jofre, J. Potential impact of environmental bacteriophages in spreading antibiotic resistance genes. Future Microbiol. 2013, 8, 739-751. [CrossRef]

176. Briers, Y.; Walmagh, M.; Van Puyenbroeck, V.; Cornelissen, A.; Cenens, W.; Aertsen, A.; Oliveira, H.; Azeredo, J.; Verween, G.; Pirnay, J.P.; et al. Engineered endolysin-based "Artilysins" to combat multidrug-resistant gram-negative pathogens. $m$ Bio 2014, 5, e01314-e01379. [CrossRef] [PubMed]

177. Ghose, C.; Euler, C.W. Gram-Negative Bacterial Lysins. Antibiotics 2020, 9, 74. [CrossRef] [PubMed]

178. Mahlein, A.K.; Kuska, M.T.; Behmann, J.; Polder, G.; Walter, A. Hyperspectral Sensors and Imaging Technologies in Phytopathology: State of the Art. Annu. Rev. Phytopathol. 2018, 56, 535-558. [CrossRef] [PubMed]

179. Holtappels, D.; Fortuna, K.; Lavigne, R.; Wagemans, J. The future of phage biocontrol in integrated plant protection for sustainable crop production. Curr. Opin. Biotechnol. 2020, 68, 60-71. [CrossRef]

180. Nagy, J.K.; Schwarzinger, I.; Künstler, A.; Pogánay, M.; Király, L. Penetration and translocation of Erwinia amylovora-specific bacteriophages in apple-A possibility of enhanced control of fire blight. Eur. J. Plant. Pathol. 2015, 142, 815-827. [CrossRef]

181. Yu, J.G.; Lim, J.A.; Song, Y.R.; Heu, S.; Kim, G.H.; Koh, Y.J.; Oh, C.S. Isolation and Characterization of Bacteriophages Against Pseudomonas syringae pv. actinidiae Causing Bacterial Canker Disease in Kiwifruit. J. Microbiol. Biotechnol. 2016, 26, 385-393. [CrossRef]

182. Jones, J.B.; Svircev, A.M.; Obradovic, A. Crop use of bacteriophages. In Bacteriophages Biology, Technology, Therapy; Harper, D.R., Abedon, S.T., Burrowes, B.H., McConville, M.L., Eds.; Springer: Cham, Switzerland, 2021; Volume 2, pp. 839-856.

183. Strauch, E.; Hammerl, J.; Hertwig, S. Bacteriophages: New tools for safer food? J. Verbr. Lebensm. 2007, 2, 138-143. [CrossRef]

184. Kahn, L.H.; Bergeron, G.; Bourassa, M.W.; De Vegt, B.; Gill, J.; Gomes, F.; Malouin, F.; Opengart, K.; Ritter, G.D.; Singer, R.S.; et al. From farm management to bacteriophage therapy: Strategies to reduce antibiotic use in animal agriculture. Ann. N. Y. Acad. Sci. 2019, 1441, 31-39. [CrossRef] [PubMed] 